NBER WORKING PAPER SERIES

\title{
HOPING TO WIN, EXPECTED TO LOSE: \\ THEORY AND LESSONS ON MICRO ENTERPRISE DEVELOPMENT
}

\author{
Dean Karlan \\ Ryan Knight \\ Christopher Udry \\ Working Paper 18325 \\ http://www.nber.org/papers/w18325
NATIONAL BUREAU OF ECONOMIC RESEARCH
1050 Massachusetts Avenue
Cambridge, MA 02138
August 2012

The authors thank USAID-BASIS and the Bill and Melinda Gates Foundation for funding, Matt Hoover for project management and research assistance, and the field staff at Innovations for Poverty Action for survey management. The authors thank the Ernst \& Young Ghana office for their collaboration, including subsidizing the consulting rates. The authors retained full intellectual freedom to report the results throughout the study. All opinions herein are our own and not those of any of the donors or partners. The views expressed herein are those of the authors and do not necessarily reflect the views of the National Bureau of Economic Research.

NBER working papers are circulated for discussion and comment purposes. They have not been peerreviewed or been subject to the review by the NBER Board of Directors that accompanies official NBER publications.

(C) 2012 by Dean Karlan, Ryan Knight, and Christopher Udry. All rights reserved. Short sections of text, not to exceed two paragraphs, may be quoted without explicit permission provided that full credit, including $\odot$ notice, is given to the source. 
Hoping to Win, Expected to Lose: Theory and Lessons on Micro Enterprise Development Dean Karlan, Ryan Knight, and Christopher Udry

NBER Working Paper No. 18325

August 2012

JEL No. D21,D24,D83,D92,L20,M13,O12

\begin{abstract}
$\underline{\text { ABSTRACT }}$
Many basic economic theories with perfectly functioning markets do not predict the existence of the vast number of microenterprises readily observed across the world. We put forward a model that illuminates why financial and managerial capital constraints may impede experimentation, and thus limit learning about the profitability of alternative firm sizes. The model shows how lack of information about one's own type, but willingness to experiment to learn one's type, may lead to short-run negative expected returns to investments on average, with some outliers succeeding. To test the model we put forward first a motivating experiment from Ghana, and second a small meta-analysis of other experiments. In the Ghana experiment, we provide inputs to microenterprises, specifically financial capital (a cash grant) and managerial capital (consulting services), to catalyze adoption of investments and practices aimed towards enterprise growth. We find that entrepreneurs invest the cash, and take the advice, but both lead to lower profits on average. In the long run, they revert back to their prior scale of operations. The small meta analysis includes results from 18 other experiments in which either capital or managerial capital were relaxed, and find mixed support for this theory.
\end{abstract}

Dean Karlan

Department of Economics

Yale University

P.O. Box 208269

New Haven, CT 06520-8629

and NBER

dean.karlan@yale.edu

Ryan Knight

Yale University

70 Winchester Ave

New Haven, CT 06511

ryan.knight@yale.edu
Christopher Udry

Yale University

udry@yale.edu 


\section{Introduction}

In developing countries, firm size within an industry often varies all the way from single-person firms to large firms. Naturally, this leads many entrepreneurs to aspire to grow, but if special managerial talent is necessary to succeed at larger scale, how do individuals learn whether they have what it takes to manage a larger enterprise? We start off with a model that incorporates heterogeneity in entrepreneurial talent, unobserved to all, to help understand the experimentation and learning process for micro-entrepreneurs about their optimal size. We show how financial and managerial capital market imperfections can impede experimentation, and thus limit learning about the profitability of alternative ways of organizing one's business.

The model makes a simple prediction: on average most businesses will not, in fact, do better after attempting to grow, but there are a few that will succeed. Specifically, relaxing credit or managerial capital constraints may allow some entrepreneurs to experiment, but such experimentation will not necessarily lead to success and in fact on average will not succeed. This is consistent with the stylized evidence that few firms transform from microenterprises into small or medium enterprises. This stagnation comes despite a plethora of effort from government, NGOs and social businesses, through for example microcredit and training. We have learned that microcredit generates important impacts but not transformational positive impacts on firm size (for credit targeted at informal sector entrepreneurs, see Attanasio et al 2011; Banerjee et al 2011; Karlan and Zinman 2011; Augsburg et al 2012; for credit targeted at individuals with some formal sector employment, see Karlan and Zinman 2009). Micro-training programs similarly generate positive but not transformational impacts (Karlan and Valdivia []; Drexler et al []; Bruhn and Zia 2011 and Berge, Bjovatn and Tungodden (2010).

We present several sources of evidence to test the model, both primary (an experiment in Ghana conducted by the authors) and secondary (a series of experiments by others, reported elsewhere and summarized here), and find mixed support empirically. The primary data source is a randomized controlled trial conducted in Ghana with microentrepreneurs, specifically tailors. We provide inputs to the tailors in the form of financial capital (a cash grant) and/or managerial capital (consulting services), to catalyze adoption of investments and practices aimed towards enterprise growth. We find that entrepreneurs invest the cash and take the advice, but both lead to lower profits on average. In the long run, they revert back to their prior operations. We do not have a large enough sample size to detect with statistical significance any positive outliers, but we present anecdotal evidence of such. We then discuss secondary evidence from other recent, similar experiments. We examine two types of experiments, cash grant experiments and lending experiments, and find evidence supporting this model (although not every result in the other papers lines up with the predictions in our model).

In the Ghana experiment, 160 tailors were randomly assigned to one of the three treatment groups or a control group. The first treatment group tests investment behavior after relaxing capital constraints by providing 200 cedi grants (about US \$133) to 38 small tailors and seamstress in and around Accra, Ghana. The second treatment group tests the managerial ability theory by providing one year of management consulting services from Ernst \& Young, a major international consulting firm, to 41 tailors. 
The third treatment group, containing 36 tailors, received both the cash grant and the managerial training. The control group contained 45 tailors.

Working with managerial consultants was not intended to test a policy per se, as their fees would likely be too high for a scalable intervention. Rather, the intent was an enterprise experiment: let four talented, creative individuals, who know the local business environment, provide mentorship and consulting services to micro-entrepreneurs to see if they could generate transformative change.

At the baseline, the microenterprises did not appear to be well managed by standards in the managerial performance literature (Bloom et al []). Only $17 \%$ of the respondents reported keeping any written financial records, $7 \%$ reported spending any money on marketing in a year and only $30 \%$ of shops were rated as very organized by our enumerators.

The context and dichotomy of experiences is perhaps well illustrated by stories of two of the respondents.

"Jess" was 26 years old, had attended vocational school to be a seamstress, and financed her start-up capital herself. She was single, with no children, and cared for a sick mother. She had a bank account but had never applied for a loan from a bank or microfinance institution. She sewed out of a wooden kiosk, and the fair value of her total capital was 765 Cedis (\$510). She carried all of her materials back and forth from her home to the shop every day because she was worried they would be stolen from her shop, which lacked a secure padlock, and had been broken into before. A strong padlock would cost about 25 Cedis (\$17), but she had drained all of her working capital from the business caring for her mother. She had recently stopped sewing for an extended period of time because caring for her mother took so much of her time, and when she returned she found that her primary clients had found another seamstress during her absence. She wanted to rebuild her customer base, but did no marketing and had no signs advertising her shop. She spoke softly, did not make eye contact and was shy with new people, but spoke briskly to well-known clients.

Across town, "Sarah" was 28 years old, had attended a polytechnic school for fashion, and inherited her business four years before the baseline. She had two bank accounts, one for business and one personal, and unlike Jess had previously received a loan. The fair value of her capital was 2730 Cedis. Sarah had two good sewing machines and a couple of special purpose machines, which she kept in her concrete shop. The quality of her sewing was good, and she was already keeping transaction records at the baseline. However, her shop was on an out-of-the-way street in a tough neighborhood, so she slept on the floor of her shop to protect her machines. She identified a new site on a main road that she wanted to move to, but she was having trouble saving up enough money. She had a natural ease with customers, but her relationships with her employee and apprentice were tense. The consultants judged Sarah to have great potential and they wanted to help her start marketing, but were concerned her location and ability to effectively manage her employees as she grew.

Both of these women appeared to face capital constraints. Jess had liquidated her business money for a personal emergency, and could not afford a small amount for a padlock to protect her investment. Sarah 
believed that a new location would be more profitable, but she could not save enough to make the move.

Both also faced managerial challenges. Jess needed to work on her customer service and needed to develop a plan to reconnect with her old clients and attract new clients. Sarah needed to learn to be a more effective manager and begin doing marketing.

Jess and Sarah both received the double treatment of the mentoring and the capital grants. At the end of the study, Jess was mourning her lost mother and hardly working. She had not reclaimed her old clients or launched any new marketing campaigns. She tried out record keeping for a time, but stopped keeping any records. She invested the capital grant in fabrics that she hoped to sell from her kiosk, but still had no padlock and was still carrying her material back and forth from home every day she worked. The consultant worked on a plan to put a little money away every day for the padlock, but she was not saving. Her profit increased from 30 Cedis in December 2008 to 80 Cedis in December 2010, half of the average increase in control group profit of 109 Cedis over the same time period.

Sarah, on the other hand, stood out for how well she adopted the consulting. With her consultant's guidance, she began "sew and sell" - sewing products with no specific customer in mind and selling them from her shop. She saved the capital grant for improvements to her new shop and expanded her record keeping. She added a small dressing room area to her shop and gave purified water satchels and candies out to clients. She designed a label with her phone number on it that she started affixing to all of the items she sewed. She successfully helped an apprentice start her own business, found a new apprentice to replace her, and hired a second employee.

Sarah's experience shows that there is much that a micro-entrepreneur can do to expand her business and improve business practices. Sarah's efforts increased her profits from 90 Cedis in December 2008 to 333 Cedis in December 2010, a substantial increase that is more than twice the average control group increase of 109 Cedis. Jess' experience shows that it is not always easy, and not everyone is capable of making large changes in their business model.

We found that, on average, the experience of the tailors was similar to that of Jess than to that of Sarah. The consultants' recommendations were adopted for a time, but the tailors had abandoned them one year after the training stop. On average, there was no positive impact on profit or revenue from the consulting and, if anything, there was a negative impact. The tailors who received the capital grant invested the money in their businesses, but these investments did not increase profits. In fact, one year after the capital grant, profit was lower among those who received the capital drop compared to the control group.

This paper proceeds as follows: Section II will put forward a theoretical model as described above, Section III will present the setting and experimental design, Section IV the data, and Section V the results from the Ghana experiment. Section VI will present the meta analysis of the other 18 experiments. Section VII concludes. 


\section{Financial Markets and Entrepreneurial Experimentation}

Imperfect financial markets, combined with non-convexities in the production technology, are the classic foundation for poverty trap arguments in the informal sector and provide a formal foundation to motivate many financial market interventions. We combine this classic model with uncertainty about the profitability of moving to a larger scale. This helps us understand why entrepreneurs in a competitive market might aggressively invest when financial market constraints are relaxed, yet achieve on average negative profits from these investments. A parallel model helps us to understand a similar pattern for business training, in which entrepreneurs at least temporarily adopt suggested new techniques that turn out to be unprofitable.

Consider two business techniques which cost $x_{l}<x_{h}$. The revenue of the low technique is $\pi\left(x_{l}\right)$ and we assume that this technique is profitable, i.e., $\pi\left(x_{l}\right)-x_{l}>0$. Every existing entrepreneur has repeatedly used technique $l$ and knows $\pi\left(x_{l}\right)$. Technique $l$ is equally profitable for all entrepreneurs. Technique $h$, however, is profitable only for some: if you are a 'good' entrepreneur, you'll get $\pi^{g}\left(x_{h}\right)$ such that $\pi^{g}\left(x_{h}\right)-x_{h}>\pi\left(x_{l}\right)-x_{l}$. On the other hand, if you are a 'bad' entrepreneur you'll earn $\pi^{b}\left(x_{h}\right)-x_{h}<\pi\left(x_{l}\right)-x_{l}$. The key is that entrepreneurs do not know their type until they invest $x_{h}$ and thus try $h$. Before trying $h$ the entrepreneur believes that her likelihood of being type $g$ is $p$. Once she tries $h$, she knows with certainty if she is of type $g .^{2}$ The entrepreneur gets instantaneous utility from consumption of $u(c)$ and maximizes the simple expected utility $E_{t} \sum_{\tau=t}^{\infty} \delta^{\tau} u\left(c_{\tau}\right)$. The entrepreneur has no access to financial markets, so if she has current assets $w$ her value function is

$$
V(w, p)=\max _{x \in\left\{x_{l}, x_{h}\right\}}\left\{\begin{array}{l}
u(w-x) \\
+1\left[x=x_{h}\right] \delta\left[p V\left(\pi^{g}\left(x_{h}\right), 1\right)+(1-p) V\left(\pi^{b}\left(x_{h}\right), 0\right)\right] \\
+1\left[x=x_{l}\right] \delta V\left(\pi\left(x_{l}\right), p\right)
\end{array}\right\},
$$

where 1[.] is the indicator function. ${ }^{3}$ The first term is current consumption. $x_{h}>x_{l}$, so consumption falls if the entrepreneur tries $h$. The second term is the future value associated with experimenting with

\footnotetext{
${ }^{2}$ The assumption that the entrepreneur learns his/her type with a single try at technique $h$ is extreme but inconsequential for the purposes of the arguments below. A richer model would have uncertain profits from technique $h$ for each type, with the distribution of returns being better for type $g$. The entrepreneur would gradually learn his or her type with repeated attempts at technique $h$.

${ }^{3}$ The assumption that the entrepreneur can neither save nor borrow simplifies the analysis tremendously, but is obviously extreme. If the entrepreneur can save at a fixed interest rate, little changes in our analysis provided that interest rate is sufficiently low (specifically, as long as $r<\frac{1-\delta}{\delta}$ ). Saving is only undertaken to smooth expected declines in consumption; it therefore lowers the cost of experimentation, but changes none of the qualitative features of the model below. Permitting borrowing as well (and setting $r=\frac{1-\delta}{\delta}$ ) is a more substantive change to the interpretation of the entrepreneur's situation, but is less realistic. Miao and Wang (2007) provide a related model with both borrowing and lending in a two-armed bandit
} 
$h$. With probability $\mathrm{p}$ the entrepreneur realizes $\pi^{g}\left(x_{h}\right)$ and (perhaps more importantly) updates $\mathrm{p}=1$. But with probability (1-p) she realizes $\pi^{b}\left(x_{l}\right)$ and updates $p=0$. The third term is the value associated with continuing to choose $x=x_{l}$.

Consider the situation where the entrepreneur knows she is a 'bad' type:

$$
V(w, 0)=\max _{x \in\left\{x_{l}, x_{h}\right\}}\left\{\begin{array}{l}
u(w-x) \\
+\delta\left[1\left(x=x_{l}\right) V\left(\pi\left(x_{l}\right), 0\right)+1\left(x=x_{h}\right) V\left(\pi^{b}\left(x_{h}\right), 0\right)\right]
\end{array}\right\},
$$

She chooses $x=x_{l}$ and consumption converges to $\pi\left(x_{l}\right)-x_{l} \equiv c_{l} \cdot V\left(\pi\left(x_{l}\right), 0\right)=\frac{1}{1-\delta} u\left(c_{l}\right)$.

In contrast, if $p=1$

$$
V(w, 1)=\max _{x \in\left\{x_{l}, x_{h}\right\}}\left\{\begin{array}{l}
u(w-x) \\
+\delta\left[1\left(x=x_{l}\right) V\left(\pi^{g}\left(x_{h}\right), 1\right)+1\left(x=x_{l}\right) V\left(\pi\left(x_{l}\right), 1\right)\right]
\end{array}\right\} .
$$

As long as $x_{h}$ is sufficiently productive, $V\left(\pi^{g}\left(x_{h}\right), 1\right)=\frac{1}{1-\delta} u\left(c_{h}\right)$, where $c_{h} \equiv \pi^{g}\left(x_{h}\right)-x_{h}$ and the entrepreneur who has sufficient capital maintains the more costly, more profitable technique. ${ }^{4}$ Obviously, $V(w, 1) \geq V(w, 0)$.

The nonconvexity in the production technology and financial market imperfection have the standard implication that a potentially profitable discrete investment may not be made. Uncertainty about the profitability of that investment helps us to understand additional patterns of behavior.

Comment 1: Sufficiently optimistic entrepreneurs will experiment with the risky, costly technique. We consider a set of entrepreneurs indexed by $\mathrm{i}$, with varying priors regarding their likelihood of being the 'good' type $p_{i}$. Each has wealth $\pi\left(x_{l}\right)$. Entrepreneur i will experiment with the high cost technique if

(3) $u\left(c_{l}\right)-u\left(\pi\left(x_{l}\right)-x_{h}\right) \leq p_{i} \frac{\delta}{1-\delta} u\left(c_{h}\right)+\left(1-p_{i}\right) \delta\left[u\left(\pi^{b}\left(x_{h}\right)-x_{l}\right)+\frac{\delta}{1-\delta} u\left(c_{l}\right)\right]-\frac{\delta}{1-\delta} u\left(c_{l}\right)$.

model with risk aversion. Many of the qualitative features of their model with no liquidity constraints are similar to our model. In particular, the entrepreneur may experiment with the high risk technique even when it has negative expected value because of its option value. They also show (when preferences are CRRA) that even when there are no liquidity constraints, increases in the wealth of the entrepreneur can induce experimentation with the risky technique. This result has implications for the interpretation of our findings, so we return to it below.

${ }^{4} u\left(\pi^{g}\left(x_{h}\right)-x_{l}\right)-u\left(\pi^{g}\left(x_{h}\right)-x_{h}\right) \leq \frac{\delta}{1-\delta}\left[u\left(\pi^{g}\left(x_{h}\right)-x_{h}\right)-u\left(\pi\left(x_{l}\right)-x_{l}\right)\right]$ is sufficiently productive. 
The LHS is the one-shot cost of trying out the high technique; the RHS is the long-term gain. The RHS of (4) is strictly increasing in $p_{i}$, and if the cost of investing in $h$ is not too high $\left(\pi\left(x_{l}\right)-x_{h}\right.$ is not too small) then there exists a $p^{*}<1$ such that $(4)$ is satisfied. All entrepreneurs with $p_{i} \geq p^{*}$ will experiment with the $h$ technique. The implication is that entrepreneurs using technique $/$ in any dataset will be those with $p_{i}<p^{*}$, which will include some fraction of those who have tried $h$ in the past and learned that they are not type $g$.

Comment 2: There is an option value to trying the risky, costly technique. Suppose that $p \pi^{g}+(1-p) \pi^{b}-x_{h}<\pi\left(x_{l}\right)-x_{l}$, so that trying the high technique has a negative expected value this period. The entrepreneur will choose $h$ if and only if

$$
V(w, p)<u\left(w-x_{h}\right)+\delta p V\left(\pi^{g}, 1\right)+\delta(1-p) V\left(\pi^{b}, 0\right) .
$$

Rearranging (5), the entrepreneur will choose $h$ iff

$$
\left(u\left(w-x_{l}\right)-u\left(w-x_{h}\right)\right)+\delta\left[u\left(c_{l}\right)-\left(p u\left(c_{h}\right)+(1-p) u\left(\pi^{b}\left(x_{h}\right)-c_{l}\right)\right)\right]
$$

$$
\leq p \frac{\delta^{2}}{1-\delta}\left(u\left(c_{h}\right)-u\left(c_{l}\right)\right)
$$

The first term on the LHS of the inequality is the immediate cost of the investment, and the second is the one-time expected loss because of the likely failure of the attempt. ${ }^{5}$ The RHS is the option value of the potential long run gain from the entrepreneur learning that she can manage a large-scale enterprise. As $\delta$ approaches 1, this option value dominates the short term costs and option $h$ is chosen.

Comment 3: Increases in the wealth of an entrepreneur reduce the critical prior belief in the likelihood of success required for that entrepreneur to experiment with the risky, costly technique. As in comment 1 , if we consider at any given level of wealth $w$ a range of entrepreneurs with prior beliefs $p_{i}$ about the likelihood that they would be successful at running a larger scale enterprise, there is a $p^{*}(w)$ such that all entrepreneurs with wealth $w$ and $p_{i}<p^{*}(w)$ choose $I$ and those with higher $p_{i}$ choose $h$. The LHS of (6) is strictly decreasing in $w$, so $\frac{d p^{*}(w)}{d w}<0$. Increases in $w$ increase the share of entrepreneurs choosing $h$. The randomized capital grants will generate investment in the enterprise, even if the immediate expected return of those investments is negative.

Comment 4: A reduction in $x_{h}$ increases the share of entrepreneurs choosing technique $h$. The LHS of (6) is strictly decreasing in $x_{h}$ (because $c_{h}=\pi^{g}\left(x_{h}\right)-x_{h}$ ), while the RHS is strictly increasing. So

\footnotetext{
${ }^{5} p \pi^{g}+(1-p) \pi^{b}-x_{h}<\pi\left(x_{l}\right)-x_{l}$ implies that $p c_{h}+(1-p)\left(\pi^{b}\left(x_{h}\right)-c_{l}\right)<c_{l}$. Concavity of u(.) ensures that $u\left(c_{l}\right)-\left(p u\left(c_{h}\right)+(1-p) u\left(\pi^{b}\left(x_{h}\right)-c_{l}\right)\right)>0$.
} 
$\frac{d p^{*}\left(x_{h}\right)}{d x_{h}}>0$. The randomized provision of consulting services lowers the cost of adopting the set of techniques associated with operating at a larger scale, so a broader set of entrepreneurs will experiment with $h$.

\section{Sample Frame and Experimental Design}

The study participants are 160 urban tailors and seamstresses in Accra, Ghana, and were randomly selected from a census we conducted of tailors and seamstresses in eight neighborhoods in/around Accra who had five or fewer total employees and apprentices. If two or more tailors were immediate neighbors, we randomly selected at most one to be in the sample frame.

We chose to work with microenterprises in the same industry because it would allow the consultants to develop some expertise in that sector, and it would allow us to gather more precise data on business practices by asking industry-specific questions in our surveys. We then wanted an industry which was geographically dispersed across Accra (to minimize possible spillovers to control groups), and also diverse in size so that there were plausibly different firm sizes that could be sustained in competitive equilibrium. One-person tailoring shops are common, but many 10-person small tailor firms also exist. We constrained our sample to tailors with 5 or fewer employees at the baseline: $35 \%$ or our sample had zero employees, and $94 \%$ had three or fewer employees. Thus, our sample frame includes very small, urban tailors and seamstresses, most of whom work directly in their shops. Also, $82.5 \%$ of our sample frame had not previously accessed formal credit markets.

We employed a $2 \times 2$ experimental design involving a 200 cedi capital grant and/or consulting services from Ernst \& Young. Figure 1 shows a full timeline of the interventions, and data collection. The consulting treatment began first, and then after eight months the second randomization assigned individuals to either receive the capital grant or not. More details are below on each treatment.

Five of the tailors passed away over the course of the study, leaving a final sample of 155 . We located 149 of the 155 tailors for the final follow-up in December 2009. Attrition is not correlated with treatment status.

Table 2 details the sample attrition. We saw no tailors permanently exit the tailoring business by selling off their machines. We did see tailors temporarily stop sewing, for health or other reasons. These individuals would be counted as having zero profit or negative profit if they had business expenses but not income. All businesses operated from the same premise by the same individual were counted in financial outcomes, so if a respondent diversified out of tailoring and into the selling of goods, income from selling the goods is counted in our data.

\section{Consulting Treatment}


We worked with one partner, a director and four consultants from Ernst \& Young in Ghana. The Ernst \& Young consultants typically work on business advisory engagements in a variety of areas including training, human resources, monitoring and evaluation and project management. Consultant bios and examples of prior engagements are in Appendix A. The consultants received a two-day training on microenterprise coaching from Ghana's National Bureau of Small Scale Industries, which frequently provides training to microenterprises in Ghana, on the Bureau's method for training microentrepreneurs.

The consultants largely followed an adapted version of this framework (outlined in Appendix A) but were also encouraged to think creatively, to discuss important business decisions facing the tailors, and to provide ad hoc advice that they felt would be beneficial. Examples of this ad hoc support can be seen in the consultants' notes in Appendix C. The training modules were twelve-fold: (1) Record Keeping, (2) Procurement, (3) Operational Activities, (4) Motivation of workers, (5) Value addition, (6) Costing, (7) Customer service, (8) Security of shop, (9) Sales and marketing, (10) Lifestyle in relation to work/life balance, (11) Financing of business and savings, and (12) Business growth.

The training took place at the tailors' shops over the course of one year, from February 2009 to February 2010. It began with lessons on the importance of record keeping, used the new records to help the tailors calculate their profit margin on each item they sew, then taught how to calculate a monthly income statement. Lessons on customer service and managing employees were discussed throughout. For example, if the consultants observed impolite behavior to customers while in the shop, they might take the opportunity to discuss customer service. The training moved at the pace of the tailors, such that some never moved past record keeping, while others began preparing cash flow statements and developing detailed plans to finance expansion.

The training involved simple, targeted lessons like, "keep your business and personal money separate"; "Buy a second wallet to keep your business money in, so you don't mix it with personal money"; and "it is better to finance expansion through savings than through loans." For those who moved past these basic lessons, there were more detailed lessons on a variety of topics, like how you should calculate how much to save to replace aging machines.

The consultants gave the tailors two record books: a standard cash book to record daily transactions; and a second book they developed to record capital stock, available materials, customer contact information, revenue, expenses and other items. The emphasis was placed first on simply recording every transaction in the cash book, then recording in the more complicated book if they were successfully tracking transactions.

As with other studies on business training, there was a surprising degree of reluctance among some tailors to make time for the consultants, and the tailors covered fewer modules than expected. The average total time spent interacting with each tailor was 10 hours over the course of the study (Figure 2). Each available tailor was visited 1-4 times per month, with each visit lasting 30 minutes to 1 hour. One of the consultants was unavailable after November 2009 and was replaced by a consultant from the National Bureau of Small Scale Industries for the final two months - the same consultant who provided 
the initial two-day training for the E\&Y team. The randomization into consulting/non-consulting was done in January 2009, stratifying only on the community in which the tailors lived.

\section{Capital Grant}

The capital grant randomization was done in October 2009, eight months after the consulting began, and was stratified on existing treatment status and community only. Deceased respondents and respondents who had permanently moved out of the study area in the first eight months of the study were excluded from the randomization, leaving 154 respondents eligible for the capital drop randomization. Of these, 75 were randomly selected to receive capital ( 37 from the consulting group and 38 from the no consulting group).

The capital grant was 200 Cedis (approximately US \$133) and unconditional. Approximately two weeks before distributing the capital grants, IPA field workers visited all the respondents to inform them that we were doing a raffle with various prizes, one of which was 200 Ghana Cedis. The respondents were given a sealed envelope that had a picture of their prize inside. The runner-up prizes were an IPAbranded keychain, $t$-shirt and mug. The field workers then explained that they would return in about two weeks with the prize. If they won the capital, we asked that they spend the money on their business, but explained that they would not have to repay the money if they spent it on personal items, and that no repayment would be required under any circumstances.

We included the two week buffer between notification and deliviery for the consultants to meet with the winning respondents to help them plan for how to use the money. However, not all consultants and tailors were available in this two week window, so not every tailor developed a plan before receiving the money.

The 200 Cedi capital drop is a little more than the average baseline working capital, defined as all cash, savings and on-hand money. The capital drop therefore represents, on average, a doubling of the reported cash available for investment. 200 Cedis is about twice baseline monthly income, about equal to one month's business expenses, and about equal to $13 \%$ of average fair market value of all baseline fixed assets (Table 1).

\section{Data}

All surveys were administered using paper/pencil questionnaires, and data entry was done in the Innovations for Poverty Action offices by Project Associates or locally-hired data entry operators. All surveys after the baseline were audited by re-administering select questions from 5-10 questionnaires by each surveyor. Surveyors were hired and monitored by Innovations for Poverty Action.

\section{Baseline survey: (1) December 2008 and (2) January 2009}

The baseline survey was conducted in two visits in order to minimize the intrusion to their daily activities (a particular concern in the first visit because it was conducted in December, during a peak season). The first, administered in December 2008, focused on financial outcomes, and the second, administered in 
January 2009, focused on business processes and attitudes. Each survey took about 40 minutes to one hour.

The first follow-up after the consulting began was conducted six months later, in July 2009 (Survey \#3), and primarily included questions on business processes.

In August 2009 (Survey \#4), we visited the respondents every other day to record how much money they received, how much they spent and how many sales they made. The goal of these visits was to get a measure of profitability that is unaffected by changes in the consulting group's understanding of how to calculate profit and ability to recall revenue/expenses.

Then in September 2009 (Survey \#5), we recorded the financial outcomes for expenses, revenue and profit.

We repeated the format from the baseline, and split measures between December 2009 (Survey \#6), focused on financial outcomes, and January 2010 (Survey \#7), focused on business process outcomes.

In December 2010 we conducted a long-term follow-up focused on financial outcomes and business processes. This survey occurred 14 months after the capital drop and 11 months after the consulting stopped.

\section{Estimation Models and Results}

The experimental design simplifies analysis. We examine a series of outcomes related to the interventions: knowledge of business practices in the consulting curriculum, adoption of these practices, investment and savings behavior, and business income and profits. This series of indicators is collected over the 8 rounds of data (although no single indicator is available for all 8 of the rounds because the questionnaires were varied to reduce respondent fatigue). A typical column in the tables that follow reports the results of a cross-sectional regression of the form

$$
y_{i t}=T_{i} \beta_{1}+\beta_{2} y_{i 0}+\beta_{3} g_{i}+N_{i} \beta_{4}+\varepsilon_{i t},
$$

where $y_{i t}$ is the outcome for tailor $\mathrm{i}$ in round $\mathrm{t}, T_{i}$ is a vector of indicators of the treatment status of tailor $\mathrm{i}, y_{i o}$ is the value of the outcome for tailor $\mathrm{i}$ in the baseline (either round 1 or round 2, depending upon the measure), $g_{i}$ is the gender of tailor $\mathrm{i}$ and $N_{i}$ is a vector of dummy variables corresponding to the neighborhood in which i operates. This specification permits a flexible examination of the timing of responses to the treatments.

\section{Results}

We divide the results into four categories: (1) impact on business literacy and business practices; (2) impact on profitability; (3) impact on investments; and (4) impact on savings and loans. 


\section{Impact on business literacy and practices}

The consulting treatment apparently succeeded in generating knowledge among treated tailors about the business practices that were a focus of the curriculum. In column 1 of Table 7 we report the results of estimating (7) where $y_{i t}$ is a measure of business literacy. In this instance, $y_{i 0}=0$, because we did not ask about business literacy until the final survey in December 2010. Eleven months after the end of the consulting, we find that being assigned to consulting (irrespective of capital treatment status) increased business literacy knowledge by an average of 0.3 questions on a 4-question quiz, which is 0.52 standard deviations.

We find that tailors who received the consulting treatment adopted the practices discussed in the curriculum, at least temporarily. Columns 3-5 report the results of estimating (7) where $y_{i t}$ is an index of the business practices encouraged by the consultants at three different times after consulting began. Business practices were measured by self-reported responses to 35 questions on various practices advocated by the consultants. Not all of the questions were asked in every round. $y_{i t}$ for columns 3 through 5 is generated by standardizing each question that was asked in that round to mean of zero and standard deviation of one, then taking the average of all questions asked in that round. This index is then re-standardized by subtracting the pre-consulting average and dividing by the pre-consulting standard deviation $y_{i 0}$ is defined as a similar index from the baseline survey.

In the 6 month follow-up (July 2009), there is a strong impact of 0.41 standard deviations on business practices, significant at the $1 \%$ level. At the one year follow-up (January 2010), this effect had diminished to 0.29 standard deviations, although the reduction from the 6 month treatment effect to the 12 month treatment effect is not statistically significant. At the two-year follow-up (December 2010), the treatment effect further diminished, to 0.12 standard deviations (although still not significantly different from that estimated in the six month follow-up).

In column 2, we estimate the effect of the consulting treatment on business practices, on average over all post-consulting rounds. The index for Column 2 was generated by standardizing each question to mean of zero and standard deviation of one, taking the average score within each question after the start of consulting, and then taking the average score across questions. The post-consulting and preconsulting rounds were then averaged, subtracted by the pre-consulting mean and divided by the preconsulting standard deviation. As can be expected, the average effect falls within the range described above for each round and it is statistically significant at the $5 \%$ level.

The consultants' foundational lesson was record keeping. The most tailors received this lesson, and this lesson was returned to most often. If the tailors learned anything from the consulting, we would expect it to be record keeping. We do indeed find a strong impact on record keeping, significant at the $1 \%$ level, with the tailors who received consulting being 45\% more likely to report keeping records in July 2009 and $23 \%$ more likely to keep records in January 2010. By December 2010, however, this point estimate had decreased to $6.5 \%$, which is statistically distinguishable from the initial $45 \%$ impact at the $1 \%$ level. 
Overall, we conclude that the consulting was successful in changing both business knowledge and behavior, although the effect on behavior diminished over time such that one year after the consulting ended there were no statistically significant differences in behavior between the consulting group and the control group.

\section{Impact on Investment}

Table 8 shows estimates of equation (7) when $y_{i t}$ is investment over the previous 12 months. Our preferred investment measure is the amount of investment in the category the tailor stated he or she would invest in when asked how they would spend an extra 200 Cedis at the baseline, as reported in Table 6. This measure has the highest power, given that we would not expect everyone to invest in the same asset class, so any average impact in an asset class would be diluted by those who preferred to invest in a different type of investment. The variables that make up the "investment in preferred category" variable are machines, property and expenses on materials.

In column 1, we see that capital grant group invested an average of 178 Cedis more than the control group by December 2009 (about two months after the grants were made in cash). The point estimate for the investment response of the consulting plus capital group is lower, only 90 Cedis. These two estimates are jointly significantly different from zero (they are not significantly different from each other). However, one year later in December 2010 this additional investment has entirely disappeared. The point estimates are tiny and insignificantly different from zero.

Columns 3-10 break the investment results down into one year results ( $\mathrm{Col} 3-6)$ and two year results (Col 7-10), and then within each year into four outcome measures: total investment, machines, property/shop and inputs. Converting the outcome measure to investment in a particular category, rather than investment in what each tailor said they would do in the baseline, leads understandably we believe to a loss of statistical power as more noise is introduced. However, the general pattern persists and is consistent with columns 1 and 2 . The first year results are generally positive, and the second year results are generally negative, although out of eight specifications only two are significant statistically.

An alternative to investing the capital drop would be saving the money. Table 9 shows our results on savings and loans. We find no statistically significant impacts on total savings or bank savings when pooling all rounds, and only find an impact on susu savings in the capital \& consulting group, whose average monthly susu savings is almost twice the baseline value of 18.6 Cedis a month (point estimate 16 , standard error 8.4). Looking at the cross-sectional impacts, we find that total savings was higher in the capital plus consulting group in the December 2009 follow-up, about two months after the capital drop (point estimate 74.5, standard error 35.7). We also find a statistically significant difference in total savings between the capital only and capital plus consulting groups, with the capital only group having lower total savings, significant at the $10 \%$ level. This might explain the higher point estimate on investment in goals seen the capital only group - the consultants reported encouraging the capital winners to top up the capital drop with their own money to make larger purchases, saving to do so if necessary. 
We find an impact on loan taking in the capital group in the months following the capital drop, but no impact in the long term (Table 10). For most tailors, the busiest time of the year is the Christmas season. Borrowing in the three months leading up to Christmas was nearly equal to borrowing in the first 6 months of the year in 2009. (Table 3)

Adding together all of the potential uses for the money (investing, saving, replacing loans), except for dividends, we find no statistically significant impacts, unless we look at investment in their goal category, savings and loan replacement, in which case we find point estimates similar in magnitude to total investment, but with much smaller standard errors, leading to statistically significant, positive impact from receiving any capital in December 2009. These results are shown in Table 10. The point estimates on capital and capital plus consulting are greater than 200 , but are not significantly different from 200. Total uses for the money one year later in December 2010 are primarily negative and insignificant.

\section{Impact on Profitability}

Our results so far show short run impacts of the consulting and capital grant treatments on behavior: knowledge and business practices improve in the consulting group and investments are made in the capital grant group. The tailors do seem to be learning about new types of techniques from the consultants (or modifying their prior beliefs about the profitability of these techniques). And the tailors are responding to the capital grant as though they are capital constrained in their business. However, in both cases we find that these changes in behavior are short-lived. After a year there is no significant difference between the capital grant or consulting groups and the control group of tailors.

An examination of profits provides an explanation for why the tailors abandoned these changes in behavior. Column 1 of Table 12 reports the results of estimating (7) where $y_{i t}$ is the tailor's stated income from his or her business, and we include individual fixed effects. ${ }^{6}$ There is no evidence that the consulting treatment is associated with higher profits. Worse, the capital grant seems to have lowered profit. The point estimate is that post-treatment income fell by almost 50 Cedis from a base of 100 Cedis for the capital grant only treatment. There is a smaller (and statistically insignificant) drop of 20 Cedis in income of the consulting plus capital grant group.

The standard errors on profit are large, relative to the means. For example, the standard error on the consulting treatment is 21.3 Cedis. To have detected an effect at the $5 \%$ level, we would have needed to observe an average change of $1.96 * 21.3=41.7$ Cedis, or $37 \%$ of the average baseline profit of 112 Cedis.

We find no statistically significant impacts on revenue. Both the consulting and the consulting \& capital groups have positive point estimates, which are large relative to the baseline average revenue, but we note fairly large standard errors. At the baseline, we asked only for average weekly revenue, weekly

\footnotetext{
${ }^{6}$ To examine business profit, we asked: After paying all expenses, what was the income of the business (the profits) during [last month] (GHS)? Consider all expenses, INCLUDING wages of employees but NOT INCLUDING any income you paid yourself or income you received from renting out land or rooms.
} 
revenue in a "good" week and weekly revenue in a bad week. In the follow-ups, we asked for revenue in the previous month to ensure that we were measuring only post-treatment outcomes that were separate from our previous surveys. ${ }^{7}$

Income is potentially subject to measurement error that is systematically correlated with treatment because the consultants' training included modules on how to calculate income. The consultants anecdotally reported that the tailors were previously not including indirect expenses when calculating income and were therefore over-estimating their profit. Income is therefore not an entirely clean measure of profitability. We therefore also report revenue less expenses in column 4 . The point estimates on revenue less expenses are similar in magnitude and direction to the point estimates on income, but are not statistically significant, except for the negative impact of receiving consulting and capital, which is significant at $10 \%$.

Revenue less expenses is an appealing alternative because it does not depend on knowledge of how to calculate profit. However, we do see an impact on record keeping, meaning that the consulting group may have better recall, and the amount of revenue and expenses is therefore not a clean measure either. To address these concerns, we visited the respondents every other day in August 2009 to ask how much money they received in the previous two days, how much they spent, how many sales they made and how many hours they worked. In August 2009, we had already seen an impact on record keeping, and were yet to do the capital drop. However, we saw no indication that for revenue, expenses, revenue less expense, hours worked, or number of sales, daily visit totals and recall measures were not more correlated for the consulting group than for the control group. Figure 4 shows the distributions of the differences between the daily visits and recall totals for revenue, expenses and revenue less expenses.

We find no evidence of changes in hours worked by the entrepreneur him or herself as a consequence of any of the treatments (column 5). Nor is there a statistically significant impact on total staff, apprentice use, or paid employees of any of the treatments (columns 6-8).

Table 12 examined the average impact of the capital, consulting and combined treatments on posttreatment profits and employment. An examination of the time path of the impacts is revealing. Recall from our earlier examination of business practices that tailors in the consulting group had adopted the advocated practices by round 3, but that the use of these practices dropped off in round 7 and then again in round 8 . We find in column 1 of Table 13 that by round 3, monthly income in the consulting group is 25 Cedis lower than in the control group. By round 5, income is (almost) statistically significantly higher in the consulting group, but in later rounds there is no difference in income between the consulting group and the control group.

The capital grant and capital plus consulting groups look worse. In round 7, after first post-grant holiday season the point estimate is that the capital (capital plus consulting) group has 50 Cedis (15 Cedis) lower

\footnotetext{
${ }^{7}$ Without a baseline measure of monthly revenue a fixed effect regression was not an option, so we instead pooled all rounds together in an OLS regression with round dummies and pre-treatment values and average weekly reported at the baseline as controls for the post-treatment rounds (so the capital group has July 2009 revenue as a control for August 2009 revenue, but the consulting group does not).
} 
income than the control, but these estimates are not statistically significant. By a year later both groups have large and statistically-significant drops in income relative to the control group. Our revenue and expense measures, reported in columns (6-11) are too noisy to permit conclusions to be drawn.

These results, unfortunately, are consistent with the model we presented above. Capital-constrained tailors respond to the relaxation of their budget constraint upon receipt of the capital grant by investing more. But why invest in activities that yield on average negative profits? Similarly they respond to the intensive consulting intervention by attempting a set of new business practices, and again are rewarded with declines in profits. Were they fooled in both instances? Perhaps, but this pattern is also consistent with entrepreneurs exploring new techniques and new levels of investment in a tentative manner in order to learn about the profitability of these innovations for themselves, knowing that on average such experiments yield a negative immediate return. Nevertheless, the option value of experimentation is sufficiently high that it is worth taking the risk. On average, as perhaps expected, the experiments yielded negative results and the innovative techniques were abandoned.

\section{Supporting Evidence from Other Studies}

We started by examining the universe of papers we are aware of that employ a randomized financial capital infusion (either through a grant or credit) to a microenterprise. This yields seven papers, three unconditional cash grant experiments and four credit experiments. ${ }^{8}$ We then examine papers with experimental infusion of managerial or entrepreneurship training. This yields 11 papers, with a wide range of intensity of intervention as well as sample frames.

From each of these papers, we test three hypotheses: (a) did the study find an average positive impact on investment, (b) conditional on finding a positive impact on investment, did the study find an average negative impact on profits for the firm, and (c) did the study find evidence of a fat right tail, i.e., of treatment leading to a small set of individuals doing considerably better than the control.

The following table summarizes the results of the above tests for each study:

\footnotetext{
${ }^{8}$ We excluded two papers which are close, but do not fit as precisely: de Mel et al (2011) which provides grants to microentrepreneurs conditional on completing formalization process in Sri Lanka (and they do find that this creates positive outliers), and Karlan and Zinman (2010) which randomly assigned credit to individuals, but with no enterprise targeting component as with more traditional microcredit.
} 


\begin{tabular}{|c|c|c|c|c|}
\hline Type of study & Citation & $\begin{array}{l}\text { Change in average } \\
\text { investment (if } \\
\text { credit or grant) or } \\
\text { change in business } \\
\text { practice (if training } \\
\text { intervention)? }\end{array}$ & $\begin{array}{l}\text { Change in average } \\
\text { profits? }\end{array}$ & $\begin{array}{l}\text { Increase in } \\
\text { likelihood of } \\
\text { extreme positive } \\
\text { profits? }\end{array}$ \\
\hline Grant & de Mel et al (2008) & Increase & Increase & Yes $^{9}$ \\
\hline Grant & Fafchamps et al (2012) & Increase $^{10}$ & Increase $^{11}$ & Yes $^{12}$ \\
\hline Grant & $\begin{array}{l}\text { Berge, Bjorvatn, } \\
\text { Tungodden (2011) }\end{array}$ & Increase (n.s.) ${ }^{13}$ & Increase (n.s.) ${ }^{14}$ & Not reported \\
\hline Credit & $\begin{array}{l}\text { Karlan and Zinman } \\
(2011)^{15}\end{array}$ & No & Increase (n.s.) & Yes $^{16}$ \\
\hline Credit & Banerjee et al (2011) & No & No & Not reported \\
\hline Credit & Attanasio et al (2012) & Increase & Decrease (n.s.) $)^{17}$ & Not reported \\
\hline Credit & Augsburg et al (2012) & Increase ${ }^{18}$ & Increase (n.s.) & Not reported \\
\hline $\begin{array}{l}\text { Skills and principles } \\
\text { training }\end{array}$ & $\begin{array}{l}\text { Karlan and Valdivia } \\
\text { (2011) }\end{array}$ & Increase $^{19}$ & Increase (n.s.) ${ }^{20}$ & Yes (n.s.) ${ }^{21}$ \\
\hline $\begin{array}{l}\text { Rules of thumb cash } \\
\text { management training }\end{array}$ & $\begin{array}{l}\text { Drexler, Fischer, and } \\
\text { Schoar }(2011)^{22}\end{array}$ & Increase $^{23}$ & Increase (n.s.) ${ }^{24}$ & Not reported \\
\hline
\end{tabular}

${ }^{9}$ Data available online on Chris Woodruff's website. Any treatment led to an increase in the probability of being in the top $5 \%$ of profits by $1.4 \%$ (s.e. $0.88 \%, p=0.105$ )

${ }^{10}$ Figure 3 (males) and Figure 4 (females), and Table 5

${ }^{11}$ Table 3, positive and statistically significant effects for in-kind grants and positive but not statistically significant effects for cash grants.

${ }^{12}$ Figure 1 (males) and Figure 2 (females)

${ }^{13}$ Table 5A, Column 3

${ }^{14}$ Table 4A, Columns 1-6

${ }^{15}$ The 2010 working paper version published online as a Yale University Economic Growth Center working paper, and not the final published version, includes the relevant results for this analysis here.

${ }^{16}$ Supplemental Table 4, available online, provides the result for average increase in profits (6.7\%, s.e. 9.7\%). In analysis conducted from the downloaded data, but not reported in the published paper, we find access to credit made individuals 3.2 percentage points (s.e. of 1.6 percentage points) more likely to have log profits above 11 , which corresponds to the top $5 \%$ of the sample frame

${ }^{17}$ Table 6, Column 5 shows a negative but not significant impact on profits on average for both group and individual liability, albeit with very large standard errors

${ }^{18}$ Table 3, Column 1 reports an increase of $5.3(\mathrm{se}=2.0)$ percentage points likelihood of ownership of inventory

${ }^{19}$ Table 2

${ }^{20}$ Table 1

${ }^{21}$ Not reported in paper. Data available at http://karlan.yale.edu/p/. In analysis conducted from the downloaded data, but not reported in the published paper, we find training led to an increase of 0.6 percentage points (s.e. 0.9) in the likelihood that normal week profits are in the top $5 \%$ of the sample frame.

22 http://www.mit.edu/ aschoar/KIS\%20DFS\%20Jan2011.pdf 


\begin{tabular}{|c|c|c|c|c|}
\hline $\begin{array}{l}\text { Principles of accounting } \\
\text { training }\end{array}$ & $\begin{array}{l}\text { Drexler, Fischer, and } \\
\text { Schoar }(2011)^{25}\end{array}$ & Increase (n.s.) & Decrease (n.s.) & Not reported \\
\hline $\begin{array}{l}\text { Eight-day training session } \\
\text { on business fundamentals } \\
\text { with hands-on activities. }\end{array}$ & $\begin{array}{l}\text { Giné and Mansuri } \\
(2011)^{26}\end{array}$ & Increase $^{27}$ & Decrease (n.s.) ${ }^{28}$ & Not reported \\
\hline $\begin{array}{l}\text { Twenty-one sessions of } \\
\text { forty-five-minute business } \\
\text { training classes with case } \\
\text { studies and role play. }\end{array}$ & $\begin{array}{l}\text { Berge, Bjorvatn, } \\
\text { Tungodden }(2011)^{29}\end{array}$ & Increase ${ }^{30}$ & $\begin{array}{l}\text { Increase for males, } \\
\text { decrease for females } \\
\text { (n.s.) }\end{array}$ & Not reported \\
\hline $\begin{array}{l}\text { Six modules on the basics } \\
\text { of accounting, investment, } \\
\text { and other business } \\
\text { fundamentals. }\end{array}$ & Bruhn and Zia (2011) ${ }^{32}$ & Increase ${ }^{33}$ & Decrease (n.s.) ${ }^{34}$ & Not reported \\
\hline $\begin{array}{l}\text { Five-months of free } \\
\text { management consulting } \\
\text { to randomly selected } \\
\text { plants of large Indian } \\
\text { textile firms. }\end{array}$ & Bloom et al (2012) ${ }^{35}$ & Increase $^{36}$ & Increase $^{37}$ & Not reported \\
\hline Three modules of business & Mano et al (2011) ${ }^{38}$ & Increase $^{39}$ & Increase ${ }^{40}$ & Not reported \\
\hline
\end{tabular}

${ }^{23}$ The rule-of-thumb course had significant and positive impacts on business practices; the accounting course had no significant impact. Table 3, column 5 shows significant impacts (at the $5 \%$ level or lower) on the order of $6-12 \%$ for the likelihood of separating business and personal cash, keeping accounting records, separating business and personal accounts, setting aside cash for business expenses, and calculating revenues formally for participants in the rule-of-thumb course. Additionally, Table 10 , column 3 shows a decrease of $9 \%$ in financial reporting inconsistencies, significant at the $10 \%$ level for the rule-of-thumb treatment group.

${ }^{24}$ Table 3 columns 5 and 3 show that sales increased more than expenses for the rule-of-thumb treatment, while expenses decreased less than sales did for the accounting principles treatment.

${ }^{25}$ http://www.mit.edu/ aschoar/KIS\%20DFS\%20Jan2011.pdf

${ }^{26}$ http://siteresources.worldbank.org/DEC/Resources/Money or Ideas.pdf

${ }^{27}$ Panel A of Table 3 shows significant and positive increase of 0.131 standard deviations in an index of business practices.

${ }^{28}$ Panel A of Table 3 shows negative but not statistically significant impact on average sales and profits $(-0.021$ standard deviations, s.e. 0.054).

${ }^{26}$ http://www.nhh.no/Admin/Public/DWSDownload.aspx?File=\%2fFiles\%2fFiler\%2finstitutter\%2fsam\%2fDiscussion+papers\%2f 2011\%2f01.11.pdf

${ }^{30}$ Table $5 \mathrm{C}$ columns 1-3 show that training increased indices of business practices around marketing, commerce and recordkeeping, $(p<0.05)$. Table 6A column 2 shows that business knowledge increased $(p<0.05)$.

${ }^{31}$ Table 4A, columns 1-6 show that male participants in business training increased profits by $20-30 \%(p<0.05)$, while female participants had decreased profits (n.s.).

${ }^{32}$ http://econ.worldbank.org/external/default/main?pagePK=64165259\&piPK=64165421\&theSitePK=469372\&menuPK=642169 26\&entitylD=000158349 20110427082512

${ }^{33}$ Table 11 column 1 shows a significant decrease of $21 \%$ in the likelihood of using a personal account for business.

${ }^{34}$ Table 9 column 1 shows a decrease (n.s.) in net profits.

${ }^{35}$ http://www.stanford.edu/ nbloom/DMM.pdf

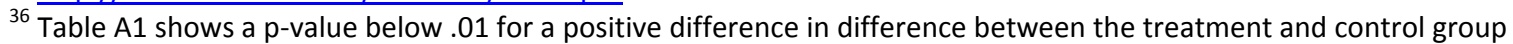
management practices before and after the treatment.

${ }^{37}$ Table A2 shows an estimated impact of $\$ 325,000$ on plant profitability for significant improvements in plant performance, tested in columns 1-8 of Table 2.

${ }^{38}$ http://wwwwds.worldbank.org/external/default/WDSContentServer/IW3P/IB/2011/08/09/000158349 20110809112532/Rendered/PDF/ WPS5755.pdf

\footnotetext{
${ }^{39}$ Table 6 columns 1-3 show significant increases in visiting customers, record keeping, and record analysis.
} 


\begin{tabular}{|l|l|l|l|l|}
\hline $\begin{array}{l}\text { training administered over } \\
\text { fifteen days. }\end{array}$ & & & \\
\hline $\begin{array}{l}\text { Classroom and on-site } \\
\text { business training. }\end{array}$ & $\begin{array}{l}\text { Sonobe and Suzuki } \\
(2011)\end{array}$ & Increase & Mixed (n.s.) & \\
\hline $\begin{array}{l}\text { Forty-seven hours of basic } \\
\text { business training for } \\
\text { female entrepreneurs. }\end{array}$ & $\begin{array}{l}\text { Calderon, Cunha, and } \\
\text { Giorgi (2011) }\end{array}$ & Increase & Not reported \\
\hline $\begin{array}{l}\text { One year of weekly } \\
\begin{array}{l}\text { consulting services from } \\
\text { local consulting firms }\end{array}\end{array}$ & $\begin{array}{l}\text { Bruhn, Karlan and Schoar } \\
(2012)\end{array}$ & Increase & Increase (n.s.) $)^{46}$ & Not reported \\
\hline
\end{tabular}

The first question, examining changes in either investment or business practice, yields a fairly consistent answer: capital does get invested, and business advice does get followed. This is true for 15 out of the 17 studies (albeit 2 of the 15 positive results are not statistically significant).

The second question, the impact on average profits, is far less clear. For capital infusions, 2 out of 7 find positive and statistically significant results, 3 find positive but not statistically significant results, one finds close to a null result, and one finds negative but not statistically significant results. Clearly this is more of a muddled pattern, indicating that while there are some cases where positive returns are strong it is not a systematic result. For training infusions, the variation in the results are much higher than the capital infusions. Out of 10 experiments, 3 report statistically significant and positive average impacts, 3 report positive but not statistically significant average impacts, and 3 report negative but not statistically significant average impacts, and one reports mixed impacts.

The third question, the creation of positive outliers, many of the studies do not report. For those that do, for capital infusion we find positive results for 3 out of 3 studies. For training studies however we are only able to examine two studies, and in neither study do we observe positive and statistically significant impacts on creation of positive outliers.

\section{Conclusion}

Canonical theories of development suggest that credit and managerial capital constraints inhibit investment and thus profits. This misallocation of resources in the economy has important implications

\footnotetext{
${ }^{40}$ Table 6 column 6 shows positive impacts of training on profits for both fabricators and machinists. The impact is significant and large for the fabricators but not significant for the machinists.

${ }^{41}$ Note: this study is ongoing and the results presented are preliminary. http://siteresources.worldbank.org/DEC/Resources/VolumelVPart2.pdf

42 Table 3-7-6 part 3 shows a positive and significant increase in total KAIZEN practices for both trainings in Tanzania. Table 4-10 shows a positive and significant impact on KAIZEN practices for both trainings in Ethiopia. Tables 5-13a \& 5-13b show a positive and significant impact on the total business practice score for both trainings in Vietnam. Tables 6-13a and 6-13b show positive and significant impact on the total score for management practices for both trainings, also in Vietnam.

${ }^{43}$ Table 3-8 column 3 shows a decrease (n.s.) in gross profits for both trainings in Tanzania. Further study is required to identify causal impacts on profits in Ethiopia (p. 324). Table 6-5 shows an increase in profits in the latest round of surveying for training groups in Ethiopia.

${ }^{44}$ http://www.stanford.edu/ gabcal/financial_literacy.pdf. Note this study is ongoing and the results are for seven months only.

${ }^{45}$ Table 3 columns 1 and 2 show positive and significant increases in keeping formal business accounts and positive increases in knowing daily and weekly profits.

${ }^{46}$ Table 3 columns 1 and 2 show positive, but not significant increases in daily and weekly profits.
} 
for growth. Yet in many (but certainly not all) situations we see interventions that infuse capital or training not seem to work as well for promoting firm or livelihood growth as one may expect, and we also see many examples of seemingly unprofitable firms, including farms (e.g., see Anagol, Etang and Karlan (2012), de Mel, McKenzie and Woodruff (2009), Duflo, Kremer and Robinson [AER May P\&P paper], Karlan, Osei, Osei and Udry (2012) and Bauchet, Morduch and Ravi (2012)).

We put forward a simple learning model, with heterogeneous types of enterprises, which helps illuminate why we may see failure on average, as well as positive outliers. Clearly no one model, particularly a simple model, accurately captures the complex reality of business operations in developing countries. Likewise not all of the predictions in our model are borne out consistently in the data of our experiment reported here, nor of the 18 studies we examined in a small meta-analysis. However, there is evidence to suggest this model provides a useful framework for thinking about the dynamics between micro and small enterprises, and the choice individual enterprise owners make when deciding to experiment with expansion or diversification.

Critical questions remain, mostly we believe along four dimensions: heterogeneity with respect to type of entrepreneur and individual, the dynamics and determinants of learning (which includes, e.g., differences in program design), market selection for interventions, and general equilibrium effects. We discuss each briefly.

What are the individual factors that should be incorporated into the model? Most importantly for both policy and modeling, what are the critical characteristics that help predict what type of individual has potential to be an outlier? Neither we nor, in our model, entrepreneurs themselves can predict who profits the most after relaxing a constraint. Are there diagnostics that could substitute for the costly experimentation otherwise required to distinguish the minority who can flourish at larger scale from those who will not? For policy, such diagnostics could be used to target more efficiently, which is particularly critical if the intervention is great for some and bad for others.

Further related questions pertain to the process of learning. Here, we have focused entirely on learning by doing and learning from formal trainers. Clearly there are many channels for learning: from one's own experience, from that of a teacher in a classroom setting, from a paid consultant, from an NGO, from a mentor with experience in one's own industry, etc. How do these different channels of learning differ in effectiveness, and why? For example, are some more credible than others, do some provide better information, are some more inspirational on a psychological level thus more likely to trigger behavior change even if the underlying information is the same, etc. Lastly, and critically, how important is it for people to see results (and how do individual entrepreneurs determine causality from process changes to outcomes), rather than merely receive information on suggested processes, in order to change behavior?

Third, markets differ in terms of competitiveness, and such interventions as discussed here should generate different impacts depending on the competitive landscape. Take the tailor experiment in Ghana as an example: perhaps the tailor industry is in perfectly competitive equilibrium, but some other industry is less so in the same geography. Understanding, and then testing, the underlying market 
factors that are necessary for success is important both for validating our models and for establishing diagnostics for policymakers and institutions interested in improving the industrial performance. For example, markets with potential product differentiation or skilled and available supply of labor may be ripe for such interventions, but those with fully competitive markets less so or even damaging.

Lastly, few if any studies have satisfactorily tackled the impact of improving one set of firms' performance on general equilibrium outcomes. The challenge is simple and obvious: if helping one firm improve its performance greatly yields a smidgeon of negative impacts for 100 other firms, it will be difficult to have sufficient statistical power to measure the smidgeons. Theory can help, as well as a focus on collecting data about the mechanisms of changes within the firm and thus the actual changes in services that customers receive. For example, if the intervention primarily teaches better persuasive marketing, but not informative marketing, then business is likely simply being shifted from one firm to another. If, on the other hand, product quality has increased, or costs have been lowered, then general equilibrium benefits are likely accruing. We believe this is a gaping hole in the entrepreneurship development literature.

\section{References}

Anagol, Santosh, Alvin Etang and Dean Karlan (2012). "Continued Existence of Cows Disproves Central Tenets of Capitalism." working paper.

Banerjee, Abhijit and Esther Duflo (2008). "Do Firms Want to Borrow More: Testing Credit Constraints Using a Targeted Lending Program," BREAD Working Paper No. 005, 2004, revised 2008.

Banerjee, Abhijit, Esther Duflo, Rachel Glennerster and Cynthia Kinnan (2009). "The miracle of microfinance? Evidence from a Randomized Evaluation", MIMEO, MIT.

Bauchet, Jonathan and Jonathan Morduch and Shamika Ravi, (2011), "Impact Assessment of An Asset Transfer Program to Ultra Poor Households", working paper.

Cole, Shawn, Thomas Sampson and Bilal Zia (2009). "Money or Knowledge? What drives demand for financial services in emerging markets?" Harvard Business School Working Paper No. 09-117.

Cole, Shawn and Guari Kartini Shastry (2009). "Smart Money: The Effect of Education, Cognative Ability, and Financial Literacy on Financial Market Participation," Harvard Business School Working Paper No. 09-071.

de Mel, Suresh and David McKenzie and Chris Woodruff (2009). "Measuring Microenterprise Profits: Must We Ask How the Sausage Is Made?" Journal of Development Economics, 88(1): 19-31.

Karlan, Dean and Isaac Osei-Akoto, Robert Osei and Chris Udry (2012). "Agricultural Decisions after Relaxing Credit and Risk Constraints", working paper. 
Karlan, Dean and Martin Valdivia (2010). "Teaching Entrepreneurship: Impact Of Business Training On Microfinance Clients and Institutions" Review of Economics and Statistics,93(2):510-527

Karlan, Dean and Jonathan Zinman (2011). "Microcredit in Theory and Practice: Using Randomized Credit Scoring for Impact Evaluation," Science, 332(6035):1278-1284.

McKenzie, David, Suresh de Mel, and Christopher Woodruff (2008). "Returns to Capital: Results from a Randomized Experiment," Quarterly Journal of Economics. 123(4): 1329-72, 2008

McKenzie, David and Christopher Woodruff (2008). "Experimental Evidence on Returns to Capital and Access to Finance in Mexico," The World Bank Economic Review 2008 22(3):457-482.

Udry, Christopher and Santosh Anagol (2006). "The Return to Capital in Ghana," American Economic Review Papers \& Proceedings, vol. 96(2), pages 388-393, May. 


\section{Figure 1: Timeline}

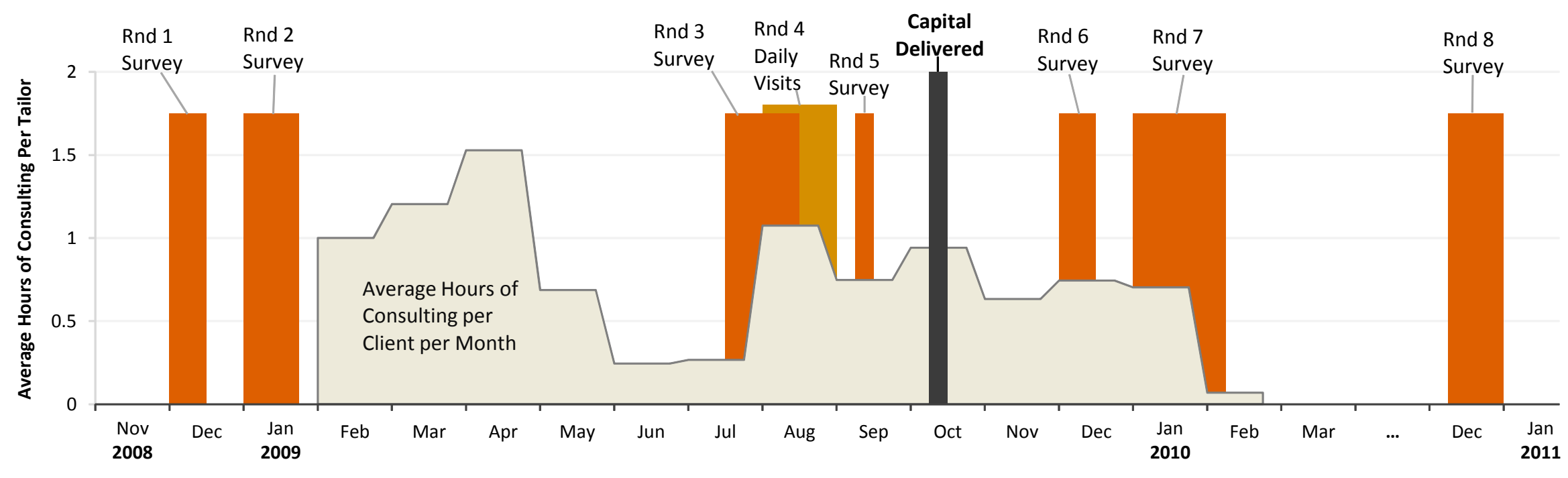

\begin{tabular}{|c|c|c|c|c|c|c|c|c|}
\hline \multicolumn{9}{|l|}{ Survey Modules } \\
\hline All Modules & Rnd 1 & Rnd 2 & Rnd 3 & Rnd 4 & Rnd 5 & $\underline{\text { Rnd } 6}$ & Rnd 7 & Rnd 8 \\
\hline Income & Income & & Income & & Income & Income & Income & Income \\
\hline Biz Overview & Biz Overview & & Biz Overview & & & Biz Overview & & Biz Overview \\
\hline Staff & Staff & & & & & Staff & & Staff \\
\hline Assets & Assets & & & & & Assets & & Assets \\
\hline Finance & Finance & & Finance & & & Finance & & Finance \\
\hline Operations & Operations & & Operations & & & & Operations & \\
\hline Rev/Expense & Rev/Expense & & & & Rev/Expense & Rev/Expense & & Rev/Expense \\
\hline Products & & Products & Products & & Products & Products & & Products \\
\hline Marketing & & Marketing & & & & & Marketing & \\
\hline Skills/Formality & & Skills/Formality & & & & & Formality & \\
\hline Household & & Household & & & & & Household & \\
\hline Financial Literacy & & Financial Literacy & & & & & & FInancial LIteracy \\
\hline Attitudes & & Attitudes & & & & & Attitudes & \\
\hline Social Networks & & Social Networks & & & & & & \\
\hline Games & & Games & & & & & Games & \\
\hline Bookkeeping & & & Bookkeeping & & & & Bookkeeping & Bookkeeping \\
\hline Quality of Consulting & & & & & & & & Quality of Consulting \\
\hline Daily Logs & & & & Daily Logs & & & & \\
\hline
\end{tabular}


Figure 2: Histogram of hours of consulting per tailor

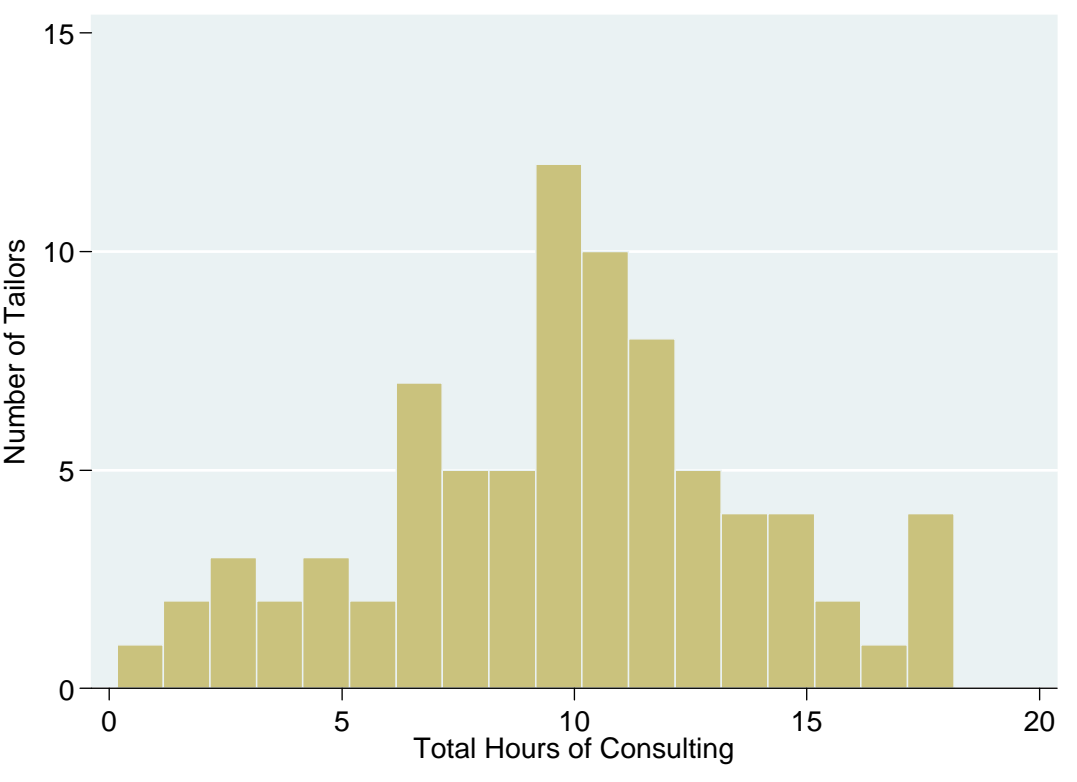


Figure 3: Mean Income by Month

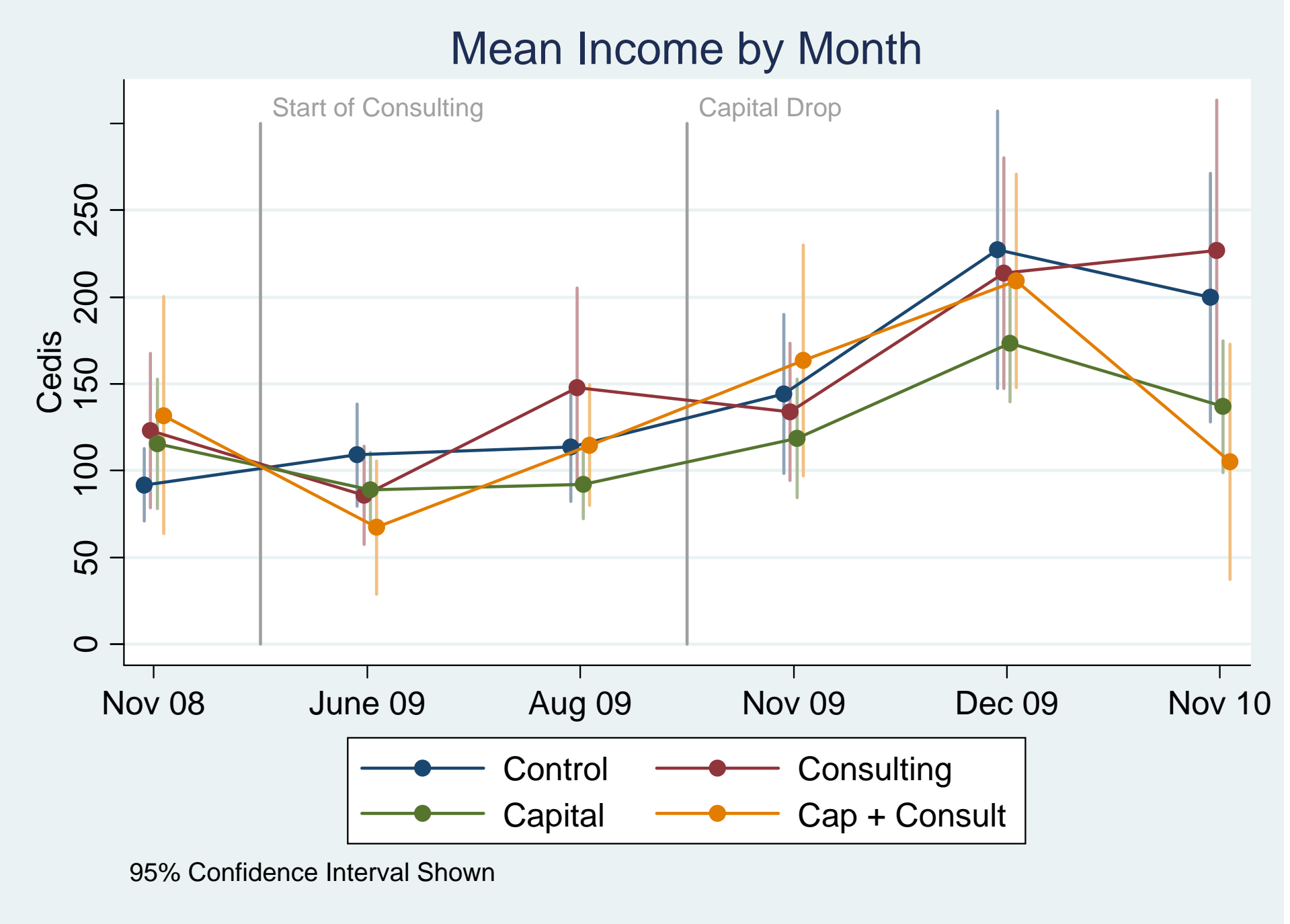




\section{Figure 4: Distributions of the Differences between Daily Visit totals and Recall amounts}
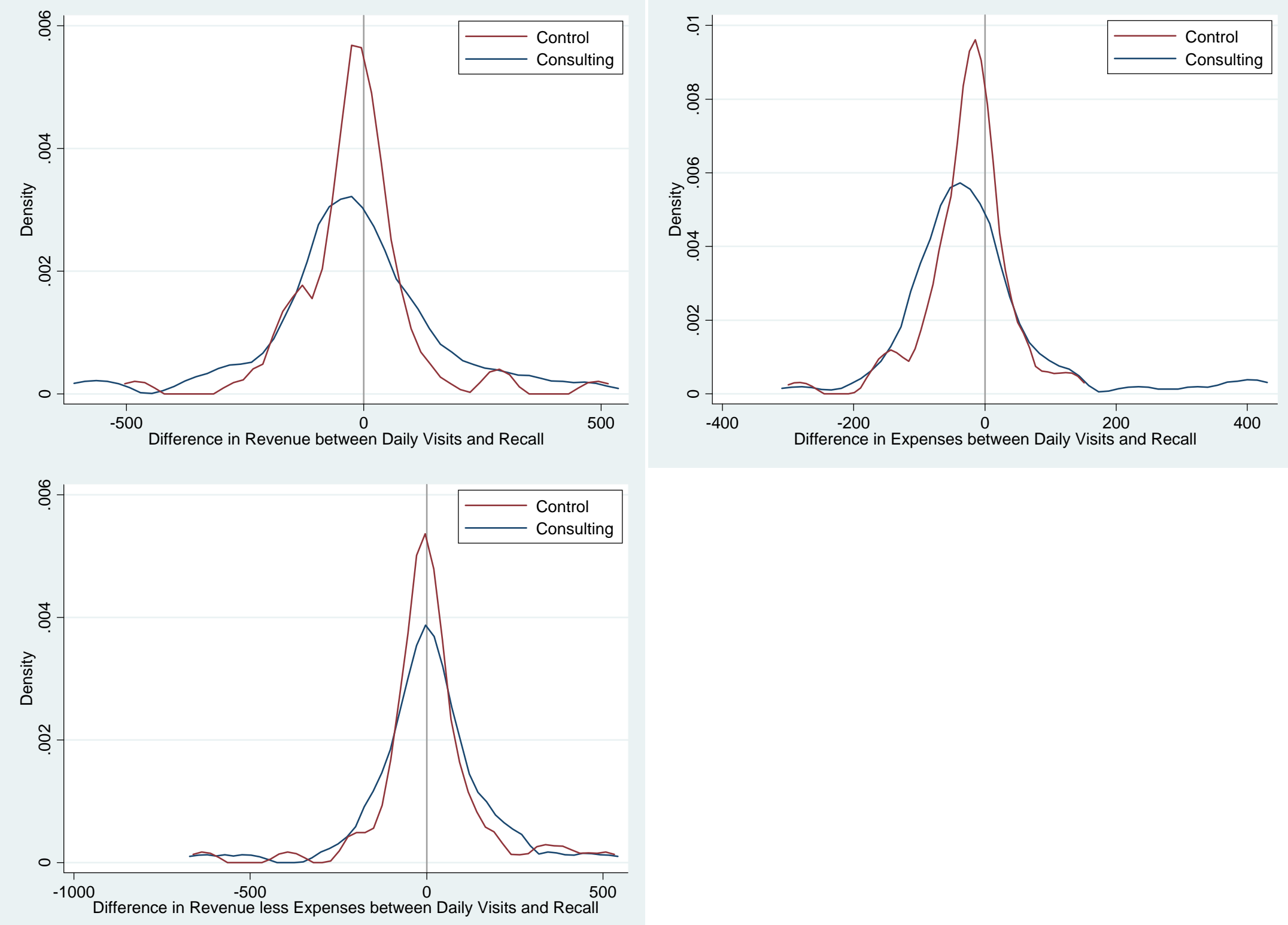
Table 1: Baseline (December 2008) Financial Metrics in Cedis

Income Last Month

Average Monthly Revenue

Monthly Expenses Excluding Rent

Working Capital

Fair Value of Fixed Assets

Number of Paid Employees

Keeps Financial Records

Has Ever Taken a Loan

\begin{tabular}{|c|c|c|c|c|c|}
\hline Mean & SD & Min & Median & Max & $\mathrm{N}$ \\
\hline 114 & 123 & 0 & 80 & 1000 & 141 \\
\hline 240 & 225 & 12 & 200 & 2000 & 154 \\
\hline 237 & 261 & 3 & 151 & 1712 & 160 \\
\hline 184 & 264 & 0 & 100 & 2000 & 156 \\
\hline 1566 & 1976 & 110 & 1140 & 20230 & 160 \\
\hline 0.4 & 0.6 & 0.0 & 0.0 & 4.0 & 160 \\
\hline 0.2 & 0.4 & 0.0 & 0.0 & 1.0 & 160 \\
\hline 0.1 & 0.3 & 0.0 & 0.0 & 1.0 & 160 \\
\hline
\end{tabular}

\section{Table 2: Attrition}

\begin{tabular}{|c|c|c|c|c|c|}
\hline Round & Deceased & $\begin{array}{c}\text { Permanently } \\
\text { Moved }\end{array}$ & Not Found & Found & Total \\
\hline 1) Dec 2008 & 0 & 0 & 0 & 160 & 160 \\
\hline 2) Jan 2009 & 0 & 0 & 0 & 160 & 160 \\
\hline 3) July 2009 & 2 & 4 & 4 & 150 & 160 \\
\hline 4) Aug 2009 & 2 & 4 & 4 & 150 (at least once) & 160 \\
\hline 5) Sept 2009 & 2 & 4 & 9 & 145 & 160 \\
\hline 6) Dec 2009 & 3 & 4 & 0 & 153 & 160 \\
\hline 7) Jan 2010 & 3 & 4 & 0 & 153 & 160 \\
\hline 8) Dec 2010 & 5 & 6 & 0 & 149 & 160 \\
\hline
\end{tabular}


Table 3: Seasonality of Borrowing

Round 1 - Dec 2008

Owe Money on a Loan Now

Round 3 - Jul 2009

Took a loan in previous 6 months

Amount Taken

Amount of Formal Loans

Round 6 - Dec 2009

Took a loan in previous $\mathbf{3}$ months

Amount Taken

Amount of Formal Loans

Round 8 - Dec 2010

Took a loan in previous $\mathbf{1 2}$ months

Amount Taken

Amount of Formal Loans

\begin{tabular}{|c|c|c|}
\hline Mean & SD & $\mathrm{N}$ \\
\hline $10.6 \%$ & 30.9 & 160 \\
\hline $10.0 \%$ & 30.1 & 150 \\
\hline 86.7 & 390.4 & 150 \\
\hline 83 & 389 & 150 \\
\hline $13.7 \%$ & 34.5 & 153 \\
\hline 69.6 & 264.7 & 153 \\
\hline 56 & 260 & 153 \\
\hline $13.4 \%$ & 34.2 & 149 \\
\hline 123.5 & 395.8 & 149 \\
\hline 89 & 348 & 149 \\
\hline
\end{tabular}

\section{Table 4: Respondent Assessment of Consultants}

\begin{tabular}{|c|c|c|c|}
\hline & \multicolumn{2}{|c|}{$\begin{array}{l}\text { Cedis Per Hour } \\
\text { Willing to Pay }\end{array}$} & \multirow[b]{2}{*}{$p==E Y$ Amount } \\
\hline & mean & SD & \\
\hline EY Consultants to Continue & 5.9 & 7.5 & \\
\hline Other Consultants Providing the Same Consulting & 2.8 & 5.1 & 0 \\
\hline Other Training of Their Choice & 4.2 & 5.4 & 0.014 \\
\hline
\end{tabular}




\section{Table 5: Randomization Check}

Difference from Mean

\begin{tabular}{|c|c|c|c|c|c|c|c|}
\hline & $\begin{array}{c}\text { Baseline } \\
\text { Mean } \\
\end{array}$ & Control & $\begin{array}{c}\text { Consulting } \\
\text { Only } \\
\end{array}$ & $\begin{array}{c}\text { Capital } \\
\text { Only } \\
\end{array}$ & $\begin{array}{c}\text { Capital \& } \\
\text { Consulting }\end{array}$ & $\begin{array}{c}\text { Model } \\
\text { F-Stat } \\
\end{array}$ & Prob > F \\
\hline & 1 & 2 & 3 & 4 & 5 & 6 & 7 \\
\hline Male & 0.43 & $\begin{array}{r}0.00777 \\
(0.0549)\end{array}$ & $\begin{array}{r}-0.0166 \\
(0.0549)\end{array}$ & $\begin{array}{l}0.0424 \\
(0.0570)\end{array}$ & $\begin{array}{r}-0.0424 \\
(0.0586)\end{array}$ & 0.297 & 0.880 \\
\hline Age & 35.29 & $\begin{array}{l}0.125 \\
(1.181)\end{array}$ & $\begin{array}{r}-1.655 \\
(1.181)\end{array}$ & $\begin{array}{l}1.816 \\
(1.227)\end{array}$ & $\begin{array}{r}-0.204 \\
(1.278)\end{array}$ & 1.048 & 0.385 \\
\hline Married & 0.56 & $\begin{array}{r}0.120 \\
(0.0772)\end{array}$ & $\begin{array}{l}0.0229 \\
(0.0772)\end{array}$ & $\begin{array}{l}-0.115 \\
(0.0802)\end{array}$ & $\begin{array}{r}-0.00694 \\
(0.0824)\end{array}$ & 1.148 & 0.336 \\
\hline Literate & 1.30 & $\begin{array}{l}0.101 \\
(0.166)\end{array}$ & $\begin{array}{r}0.0421 \\
(0.164)\end{array}$ & $\begin{array}{r}-0.0561 \\
(0.172)\end{array}$ & $\begin{array}{r}-0.0708 \\
(0.177)\end{array}$ & 0.175 & 0.951 \\
\hline Number of Children & 1.24 & $\begin{array}{r}0.343^{*} \\
(0.205)\end{array}$ & $\begin{array}{r}-0.120 \\
(0.205)\end{array}$ & $\begin{array}{r}-0.103 \\
(0.219)\end{array}$ & $\begin{array}{r}-0.0420 \\
(0.222)\end{array}$ & 0.853 & 0.494 \\
\hline Shop is cement & 0.21 & $\begin{array}{l}0.0620 \\
(0.0630)\end{array}$ & $\begin{array}{l}0.0620 \\
(0.0630)\end{array}$ & $\begin{array}{r}-0.0484 \\
(0.0654)\end{array}$ & $\begin{array}{r}-0.0951 \\
(0.0672)\end{array}$ & 1.123 & 0.348 \\
\hline Stated Income & 113.99 & $\begin{array}{r}-22.20 \\
(19.94)\end{array}$ & $\begin{array}{l}8.924 \\
(20.75)\end{array}$ & $\begin{array}{l}1.570 \\
(22.01)\end{array}$ & $\begin{array}{l}17.84 \\
(22.74)\end{array}$ & 0.511 & 0.728 \\
\hline Revenue & 240.21 & $\begin{array}{l}3.392 \\
(35.79)\end{array}$ & $\begin{array}{r}61.50 * \\
(35.35)\end{array}$ & $\begin{array}{r}-36.21 \\
(38.26)\end{array}$ & $\begin{array}{r}-32.62 \\
(38.81)\end{array}$ & 1.160 & 0.331 \\
\hline Expenses & 247.66 & $\begin{array}{l}33.66 \\
(41.63)\end{array}$ & $\begin{array}{r}-16.56 \\
(41.63)\end{array}$ & $\begin{array}{l}6.848 \\
(43.24)\end{array}$ & $\begin{array}{r}-19.59 \\
(44.42)\end{array}$ & 0.258 & 0.904 \\
\hline Apprentices & 0.86 & $\begin{array}{r}-0.204 \\
(0.171)\end{array}$ & $\begin{array}{r}0.430 * * \\
(0.171)\end{array}$ & $\begin{array}{r}-0.205 \\
(0.178)\end{array}$ & $\begin{array}{r}-0.0292 \\
(0.183)\end{array}$ & 2.263 & 0.0649 \\
\hline Employees & 0.35 & $\begin{array}{r}-0.00854 \\
(0.0984)\end{array}$ & $\begin{array}{r}-0.0329 \\
(0.0984)\end{array}$ & $\begin{array}{l}0.124 \\
(0.102)\end{array}$ & $\begin{array}{r}-0.1000 \\
(0.105)\end{array}$ & 0.623 & 0.647 \\
\hline Fixed Assets & 1566.01 & $\begin{array}{r}-72.22 \\
(312.1)\end{array}$ & $\begin{array}{r}-125.3 \\
(312.1)\end{array}$ & $\begin{array}{l}457.0 \\
(324.2)\end{array}$ & $\begin{array}{r}-260.8 \\
(333.0)\end{array}$ & 0.704 & 0.590 \\
\hline Current Assets & 457.28 & $\begin{array}{r}-8.055 \\
(169.4)\end{array}$ & $\begin{array}{r}-65.10 \\
(169.4)\end{array}$ & $\begin{array}{r}-161.4 \\
(175.9)\end{array}$ & $\begin{array}{l}278.6 \\
(180.8)\end{array}$ & 0.842 & 0.501 \\
\hline Keeps Records & 0.17 & $\begin{array}{r}-0.0224 \\
(0.0594)\end{array}$ & $\begin{array}{r}-0.0468 \\
(0.0594)\end{array}$ & $\begin{array}{l}0.0681 \\
(0.0617)\end{array}$ & $\begin{array}{l}0.0257 \\
(0.0634)\end{array}$ & 0.536 & 0.710 \\
\hline Registered Business & 0.53 & $\begin{array}{l}0.0297 \\
(0.0788)\end{array}$ & $\begin{array}{r}0.00534 \\
(0.0788)\end{array}$ & $\begin{array}{l}0.0214 \\
(0.0818)\end{array}$ & $\begin{array}{r}-0.00347 \\
(0.0841)\end{array}$ & 0.0543 & 0.994 \\
\hline Social Network Size & 2.81 & $\begin{array}{r}-0.0808 \\
(0.289)\end{array}$ & $\begin{array}{r}0.0168 \\
(0.289)\end{array}$ & $\begin{array}{r}-0.0757 \\
(0.300)\end{array}$ & $\begin{array}{l}0.271 \\
(0.308)\end{array}$ & 0.230 & 0.922 \\
\hline Digits Backward & 3.11 & $\begin{array}{r}-0.0881 \\
(0.0997)\end{array}$ & $\begin{array}{r}-0.0637 \\
(0.0997)\end{array}$ & $\begin{array}{r}0.0980 \\
(0.104)\end{array}$ & $\begin{array}{r}0.0264 \\
(0.106)\end{array}$ & 0.537 & 0.709 \\
\hline
\end{tabular}

Notes: Standard errors and F-Stat are from a regression of de-meaned baseline values against all four groups with no constant 
Table 6: Stated Uses of Capital

\begin{tabular}{|c|c|c|c|c|c|}
\hline \multirow{2}{*}{$\begin{array}{c}\text { Hypothetical } \\
\text { Likely Use for } \\
200 \text { Cedi Grant } \\
\text { (at baseline) }\end{array}$} & \multicolumn{4}{|c|}{$\begin{array}{c}\text { Actual Use for } 200 \text { Cedi Grant } \\
\text { (self reported after capital drop) }\end{array}$} & \multirow[b]{2}{*}{$\begin{array}{c}\text { Total Baseline } \\
\text { Likely Uses }\end{array}$} \\
\hline & Machines & Property & Inputs & Other & \\
\hline \multicolumn{6}{|l|}{ Consulting \& Capital } \\
\hline Machines & 0 & 0 & 1 & 3 & 4 \\
\hline Property & 0 & 2 & 2 & 0 & 5 \\
\hline Inputs & 7 & 1 & 9 & 12 & 27 \\
\hline Other & 0 & 0 & 0 & 0 & 0 \\
\hline Total Consult \& Capital & 7 & 3 & 12 & 15 & 36 \\
\hline \multicolumn{6}{|l|}{ Capital Only } \\
\hline Machines & 2 & 2 & 1 & 0 & 5 \\
\hline Property & 0 & 1 & 1 & 1 & 3 \\
\hline Inputs & 5 & 4 & 17 & 7 & 30 \\
\hline Other & 0 & 0 & 0 & 0 & 0 \\
\hline Total Capital Only & 7 & 7 & 19 & 8 & 38 \\
\hline \multicolumn{6}{|l|}{ Overall } \\
\hline Machines & 2 & 2 & 2 & 3 & 9 \\
\hline Property & 0 & 3 & 3 & 1 & 8 \\
\hline Inputs & 12 & 5 & 26 & 19 & 57 \\
\hline Other & 0 & 0 & 0 & 0 & 0 \\
\hline Overall Total & 14 & 10 & 31 & 23 & 74 \\
\hline
\end{tabular}

Note: Some people split the money into different categories,

so reported uses are greater than the number baseline likely uses

Other uses includes saving, domestic use and paying down debt

Chi2 that distribution of Consulting \& Capital uses $=$ Capital Only uses $=7.5, p=.19$ 
Table 7: Business Literacy and Practices

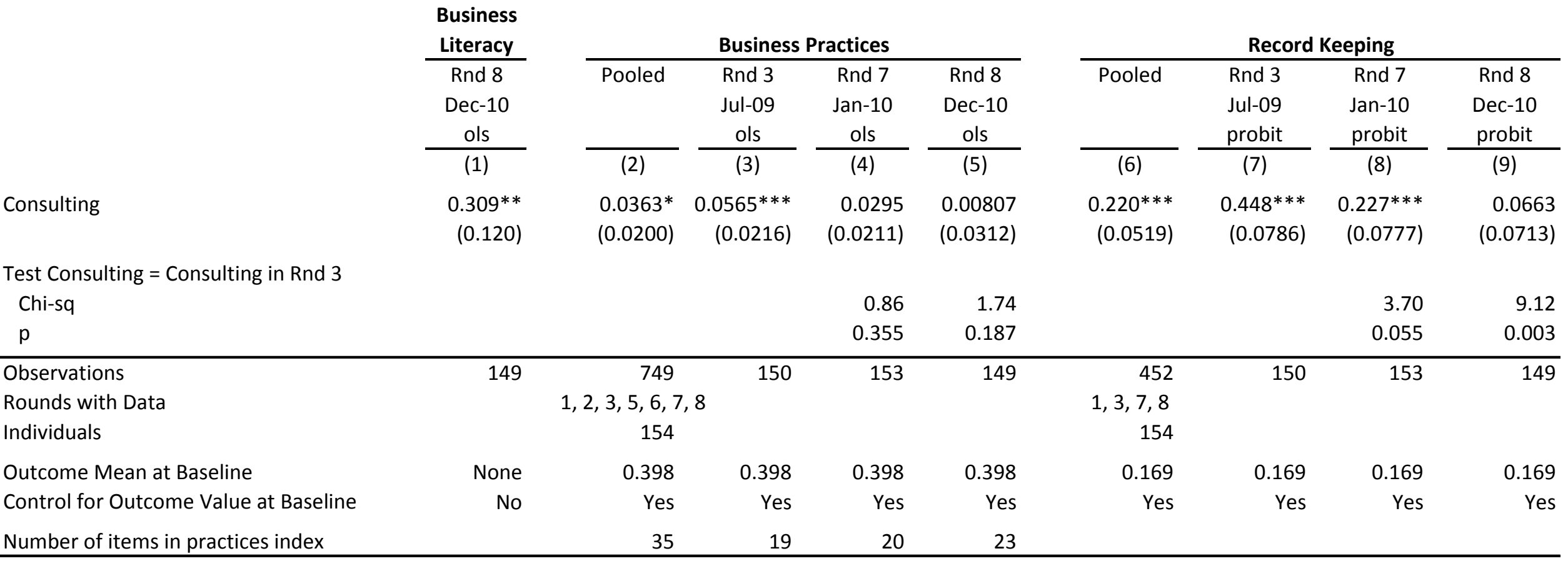

$* \mathrm{p}<.10, * * \mathrm{p}<.05, * * * \mathrm{p}<.01$

Standard errors in parenthesis

All regressions include dummies for which neighborhood the tailors lived in at the baseline.

Consulting in this table includes both individuals assigned to Consulting and individuals assigned to Consulting and Capital

Business literacy is the number of answers correct on a 4 question test of business literacy

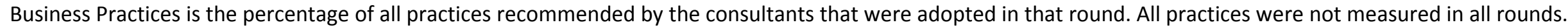

Record Keeping is whether the respondent stated that they keep financial records.

Round-by-round record keeping regressions are probit models with marginal effects reported

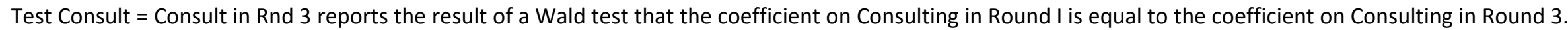


Table 8: Investment

\begin{tabular}{|c|c|c|c|c|c|c|c|c|c|c|}
\hline & \multirow{3}{*}{\multicolumn{2}{|c|}{$\begin{array}{l}\text { Actual Investment in } \\
\text { Category of Likely Use for } \\
200 \text { Cedi Grant at Baseline }\end{array}$}} & \multicolumn{8}{|c|}{ Investments Made During Previous Year } \\
\hline & & & \multicolumn{4}{|c|}{ Dec-09 } & \multicolumn{4}{|c|}{ Dec-10 } \\
\hline & & & \multirow{2}{*}{$\begin{array}{c}\text { Total } \\
\text { Investment }\end{array}$} & \multicolumn{3}{|c|}{ Property/ } & \multirow{2}{*}{$\begin{array}{c}\text { Total } \\
\text { Investment }\end{array}$} & \multicolumn{3}{|c|}{ Property/ } \\
\hline & Dec-09 & Dec-10 & & Machines & Shop & Inputs & & Machines & Shop & Inputs \\
\hline & ols & ols & ols & ols & ols & ols & ols & ols & ols & ols \\
\hline & 1 & 2 & 3 & 4 & 5 & 6 & 7 & 8 & 9 & 10 \\
\hline Consulting Only & $\begin{array}{r}11.33 \\
(90.89)\end{array}$ & $\begin{array}{r}-72.74 \\
(85.75)\end{array}$ & $\begin{array}{r}151.6 \\
(270.8)\end{array}$ & $\begin{array}{r}-61.56 \\
(72.66)\end{array}$ & $\begin{array}{r}211.8 \\
(226.5)\end{array}$ & $\begin{array}{r}-5.396 \\
(27.49)\end{array}$ & $\begin{array}{r}-175.9 \\
(184.5)\end{array}$ & $\begin{array}{r}-32.57 \\
(57.09)\end{array}$ & $\begin{array}{r}-36.55 \\
(106.1)\end{array}$ & $\begin{array}{r}-35.76 \\
(59.94)\end{array}$ \\
\hline Capital Only & $\begin{array}{l}179.3^{*} \\
(92.13)\end{array}$ & $\begin{array}{r}-13.70 \\
(88.96)\end{array}$ & $\begin{array}{r}73.52 \\
(274.7)\end{array}$ & $\begin{array}{r}-85.88 \\
(73.75)\end{array}$ & $\begin{array}{r}166.8 \\
(229.5)\end{array}$ & $\begin{array}{l}46.35^{*} \\
(27.52)\end{array}$ & $\begin{array}{c}-378.3 * \\
(191.6)\end{array}$ & $\begin{array}{c}-106.0 * \\
(59.31)\end{array}$ & $\begin{array}{r}-123.9 \\
(110.0)\end{array}$ & $\begin{array}{l}-21.52 \\
(61.30)\end{array}$ \\
\hline Consulting \& Capital & $\begin{array}{r}89.57 \\
(93.34) \\
\end{array}$ & $\begin{array}{r}-64.92 \\
(88.00) \\
\end{array}$ & $\begin{array}{r}269.0 \\
(278.7) \\
\end{array}$ & $\begin{array}{r}54.75 \\
(74.66) \\
\end{array}$ & $\begin{array}{r}199.4 \\
(232.8) \\
\end{array}$ & $\begin{array}{r}21.12 \\
(28.16) \\
\end{array}$ & $\begin{array}{r}-66.51 \\
(189.7) \\
\end{array}$ & $\begin{array}{r}-13.64 \\
(58.62) \\
\end{array}$ & $\begin{array}{r}63.45 \\
(108.9) \\
\end{array}$ & $\begin{array}{r}9.693 \\
(61.37) \\
\end{array}$ \\
\hline \multicolumn{11}{|l|}{$p$ value on tests of joint significance } \\
\hline Consulting \& Capital with Consulting & 0.53 & 0.36 & 0.38 & 0.96 & 0.30 & 0.75 & 0.46 & 0.65 & 0.89 & 0.81 \\
\hline $\begin{array}{c}\text { Consulting \& Capital with Capital } \\
\text { p value on tests of equality of means }\end{array}$ & 0.10 & 0.61 & 0.47 & 0.81 & 0.36 & 0.16 & 0.18 & 0.24 & 0.75 & 0.91 \\
\hline Consulting \& Capital = Consulting & 0.40 & 0.93 & 0.67 & 0.12 & 0.96 & 0.34 & 0.56 & 0.74 & 0.35 & 0.45 \\
\hline Consulting \& Capital = Capital & 0.34 & 0.57 & 0.49 & 0.06 & 0.89 & 0.37 & 0.11 & 0.13 & 0.10 & 0.61 \\
\hline Observations & 153 & 149 & 153 & 153 & 153 & 153 & 149 & 149 & 149 & 149 \\
\hline
\end{tabular}

$* \mathrm{p}<.10, * * \mathrm{p}<.05, * * * \mathrm{p}<.01$

Standard errors in parenthesis

All variables winsorized at the highest $1 \%$

See table 1 for breakdown of likely investment categories at baseline.

All regressions include baseline asset controls and dummies for community 
Actual Investment in Category of Likely Use for 200 Cedi Grant at Baseline $\frac{\text { Dec-09 }}{\text { ols }} \frac{\text { Dec-10 }}{\text { ols }}$ 1

Consulting Only

Capital Only

Consulting \& Capital

$-64.92$

(93.34) (88.00)

\begin{tabular}{|c|c|c|c|c|c|c|c|}
\hline \multicolumn{8}{|c|}{ Asset Stock } \\
\hline \multicolumn{4}{|c|}{ Dec-09 } & \multicolumn{4}{|c|}{ Dec-10 } \\
\hline $\begin{array}{c}\text { Total } \\
\text { Assets }\end{array}$ & Machines & $\begin{array}{c}\text { Property/ } \\
\text { Shop } \\
\end{array}$ & Inventory & $\begin{array}{c}\text { Total } \\
\text { Assets }\end{array}$ & Machines & $\begin{array}{c}\text { Property/ } \\
\text { Shop } \\
\end{array}$ & Inventory \\
\hline ols & ols & ols & ols & ols & ols & ols & ols \\
\hline 3 & 4 & 5 & 6 & 7 & 8 & 9 & 10 \\
\hline 151.6 & -61.56 & 211.8 & 10.08 & -175.9 & -104.5 & 167.4 & -116.3 \\
\hline (270.8) & $(72.66)$ & (226.5) & (36.78) & (184.5) & $(118.6)$ & $(250.2)$ & (113.0) \\
\hline 73.52 & -85.88 & 166.8 & 39.87 & $-378.3^{*}$ & $-206.4^{*}$ & 31.71 & -151.4 \\
\hline (274.7) & (73.75) & (229.5) & $(37.25)$ & (191.6) & (123.3) & (259.5) & (117.1) \\
\hline 269.0 & 54.75 & 199.4 & $75.24 * *$ & -66.51 & 31.11 & 254.4 & -117.9 \\
\hline (278.7) & (74.66) & (232.8) & (37.79) & (189.7) & $(121.8)$ & (257.0) & (116.1) \\
\hline
\end{tabular}

$p$ value on tests of joint significance Consulting \& Capital with Consulting

Consulting \& Capital with Capital

$$
0.5
$$

0.53

0.36

0.38

0.96

0.30

0.19

0.46

(1)

(116.1)

$p$ value on tests of equality of means

Consulting \& Capital = Consulting

$0.40 \quad 0.93$

0.47

0.81

0.36

0.67

0.34

0.57

0.49

0.12

0.06

$153 \quad 153$

$153 \quad 153$

$153 \quad 153$

\begin{tabular}{l}
0.46 \\
0.18 \\
0.56 \\
0.11 \\
\hline 149
\end{tabular}

0.72
0.41

$\begin{array}{ll}0.34 & 0.24 \\ 0.52 & 0.18 \\ & \\ 0.73 & 0.99 \\ 0.40 & 0.78\end{array}$

${ }^{*} \mathrm{p}<.10,{ }^{* *} \mathrm{p}<.05,{ }^{* * *} \mathrm{p}<.01$

Standard errors in parenthesis

All variables winsorized at the highest $1 \%$

See table 1 for breakdown of likely investment categories at baseline.

All regressions include dummies for community and baseline asset values in each category 


\section{Table 9: Savings}

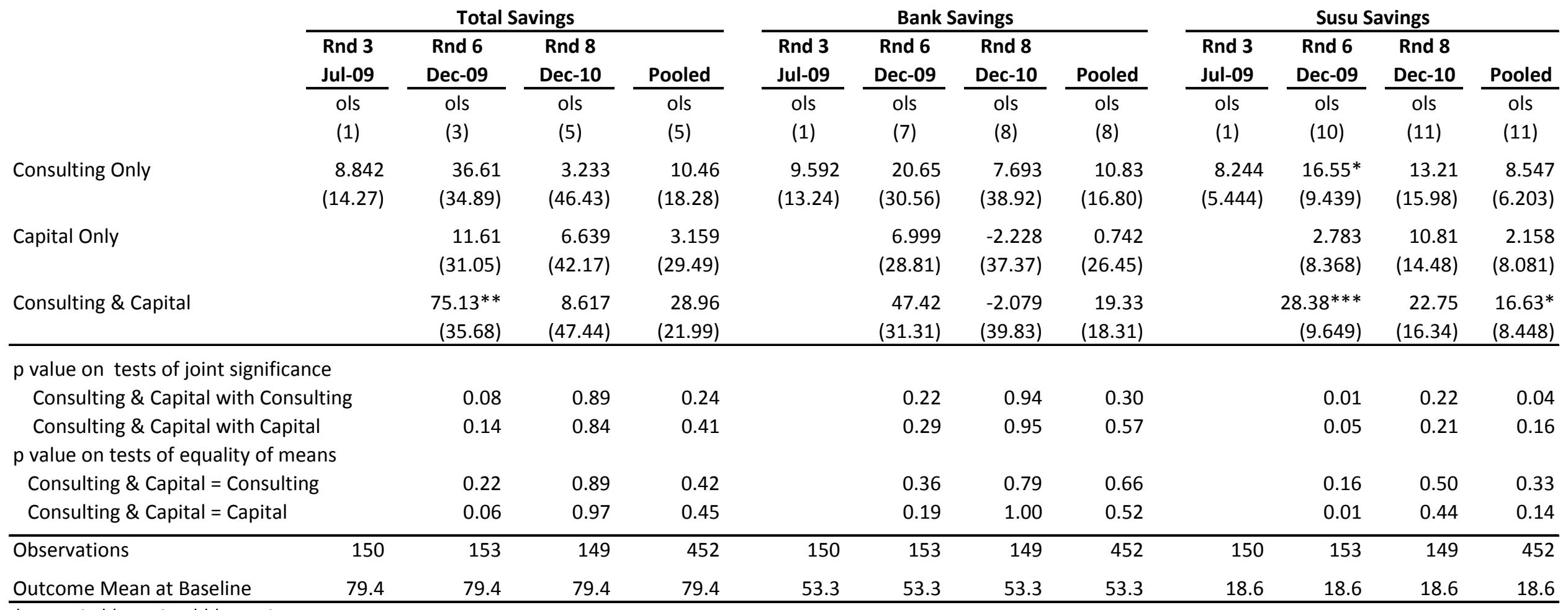

$* \mathrm{p}<.10, * * \mathrm{p}<.05, * * * \mathrm{p}<.01$

Standard errors in parenthesis

Controls for baseline value and community in all regressions

Revenue and expenses are winsorized at the highest $1 \%$ and income is winsorized at the highest and lowest $1 \%$ 
Table 10: Loan Taking and Combined Investment, savings and loans

\begin{tabular}{|c|c|c|c|c|c|c|}
\hline & \multicolumn{2}{|c|}{ Loan Amounts } & \multicolumn{2}{|c|}{$\begin{array}{l}\text { Investment in Goal, } \\
\text { Savings, and } \\
\text { Avoided Loans } \\
\end{array}$} & \multicolumn{2}{|c|}{$\begin{array}{l}\text { Total Investment, } \\
\text { Savings, and } \\
\text { Avoided Loans }\end{array}$} \\
\hline & Dec-09 & Dec-10 & Dec-09 & Dec-10 & Dec-09 & Dec-10 \\
\hline & ols & ols & ols & ols & ols & ols \\
\hline & 1 & 2 & 3 & 4 & 5 & 6 \\
\hline \multirow[t]{2}{*}{ Consulting Only } & -55.82 & -31.71 & 67.35 & -42.43 & 211.6 & -54.14 \\
\hline & $(55.47)$ & $(88.69)$ & (113.1) & (113.9) & $(286.7)$ & $(149.3)$ \\
\hline \multirow[t]{2}{*}{ Capital Only } & $-135.6 * *$ & 21.75 & $326.2 * * *$ & -43.32 & 191.5 & -245.6 \\
\hline & $(55.40)$ & $(90.56)$ & $(114.6)$ & $(118.2)$ & (290.6) & (154.9) \\
\hline \multirow[t]{2}{*}{ Consulting \& Capital } & -85.09 & 13.12 & $229.3^{*}$ & -69.13 & 400.0 & 17.27 \\
\hline & $(56.99)$ & $(91.06)$ & $(116.3)$ & $(117.1)$ & $(294.9)$ & $(153.4)$ \\
\hline \multicolumn{7}{|l|}{$p$ value on tests of joint significance } \\
\hline Consulting \& Capital with Consultin & 0.15 & 0.91 & 0.14 & 0.58 & 0.23 & 0.89 \\
\hline Consulting \& Capital with Capital & $0.02 * *$ & 0.82 & $0.01 * * *$ & 0.58 & 0.24 & 0.39 \\
\hline \multicolumn{7}{|l|}{$p$ value on tests of equality of means } \\
\hline Consulting \& Capital = Consulting & 0.60 & 0.61 & 0.16 & 0.82 & 0.52 & 0.64 \\
\hline Consulting \& Capital = Capital & 0.38 & 0.93 & 0.41 & 0.83 & 0.48 & $0.10 *$ \\
\hline Observations & 153 & 149 & 153 & 149 & 153 & 149 \\
\hline
\end{tabular}

${ }^{*} \mathrm{p}<.10,{ }^{* *} \mathrm{p}<.05, * * * \mathrm{p}<.01$

Standard errors in parenthesis

Columns 1 and 2 winsorized at the highest 1\%. Columns 3-5 winsorized at highest and lowest $1 \%$

See table 1 for breakdown of likely investment categories at baseline.

Controls for baseline value and community in all regressions

Columns 3 and 4 are investment in goal category plus savings minus loans taken

Columns 5 and 6 are total investment plus savings minus loans taken 
Table 11: Investment Heterogeneity

\begin{tabular}{|c|c|c|c|c|}
\hline & & & & \\
\hline & $\begin{array}{r}\text { Actual In } \\
\text { Category of } \\
200 \text { Cedi Gr }\end{array}$ & $\begin{array}{l}\text { tment in } \\
\text { ely Use for } \\
\text { at Baseline }\end{array}$ & $\begin{array}{c}\text { Investment } \\
\text { in Goal } \\
\text { Self }\end{array}$ & $\begin{array}{c}\text { Investment } \\
\text { in Goal } \\
\text { Uncertainty }\end{array}$ \\
\hline & Dec-09 & Dec-10 & Commitment & Aversion \\
\hline & ols & ols & ols & ols \\
\hline & 1 & 2 & 3 & 4 \\
\hline Consulting Only & 11.33 & -72.74 & 12.70 & 3.871 \\
\hline & (90.89) & $(85.75)$ & $(85.23)$ & (160.4) \\
\hline Capital Only & 179.3* & -13.70 & $218.7^{* *}$ & -57.12 \\
\hline & (92.13) & (88.96) & $(85.60)$ & (148.7) \\
\hline Consulting \& Capital & 89.57 & -64.92 & 82.20 & 121.2 \\
\hline & (93.34) & $(88.00)$ & $(86.61)$ & (153.9) \\
\hline Consulting Only*Self & ment & & 136.3 & \\
\hline & & & (137.2) & \\
\hline Capital Only*Self Cor & & & $-382.6 * * *$ & \\
\hline & & & $(133.0)$ & \\
\hline Consulting \& Capital & nmitment & & 70.66 & \\
\hline & & & (136.1) & \\
\hline Consulting Only*Unce & Averse & & & 5.030 \\
\hline & & & & (53.03) \\
\hline Capital Only*Uncerta & & & & $103.3^{* *}$ \\
\hline & & & & $(49.81)$ \\
\hline Consulting \& Capital* & inty Averse & & & -9.580 \\
\hline & & & & (49.09) \\
\hline Observations & 153 & 149 & 153 & 153 \\
\hline
\end{tabular}

${ }^{*} \mathrm{p}<.10, * * \mathrm{p}<.05, * * * \mathrm{p}<.01$

Standard errors in parenthesis

All variables winsorized at the highest $1 \%$

See table 1 for breakdown of likely investment categories at baseline.

Controls for baseline value and community in all regressions 
Table 12: Profitability Pooled

\begin{tabular}{|c|c|c|c|c|c|c|c|c|}
\hline & $\begin{array}{c}\text { Stated } \\
\text { Income } \\
\text { Pooled } \\
(1)\end{array}$ & $\begin{array}{c}\text { Revenue } \\
\text { Pooled } \\
\text { (2) }\end{array}$ & $\begin{array}{c}\text { Expenses } \\
\text { Pooled } \\
\text { (3) }\end{array}$ & $\begin{array}{c}\begin{array}{c}\text { Revenue } \\
\text { less } \\
\text { Expenses }\end{array} \\
\text { Pooled } \\
\text { (4) }\end{array}$ & $\begin{array}{c}\begin{array}{c}\text { Hours } \\
\text { Worked }\end{array} \\
\text { per Month } \\
\begin{array}{c}\text { Pooled } \\
(5)\end{array}\end{array}$ & $\begin{array}{c}\text { Total } \\
\text { Staff } \\
\text { Pooled } \\
(6)\end{array}$ & $\begin{array}{c}\text { Apprentices } \\
\text { Pooled } \\
\text { (7) }\end{array}$ & $\begin{array}{c}\begin{array}{c}\text { Paid } \\
\text { Employees }\end{array} \\
\begin{array}{c}\text { Pooled } \\
(8)\end{array}\end{array}$ \\
\hline Consulting Only & $\begin{array}{r}0.905 \\
(21.42)\end{array}$ & $\begin{array}{r}-33.34 \\
(38.76)\end{array}$ & $\begin{array}{r}-18.24 \\
(29.97)\end{array}$ & $\begin{array}{r}-15.89 \\
(22.35)\end{array}$ & $\begin{array}{r}2.325 \\
(11.40)\end{array}$ & $\begin{array}{l}0.0565 \\
(0.205)\end{array}$ & $\begin{array}{l}0.0687 \\
(0.157)\end{array}$ & $\begin{array}{l}0.0474 \\
(0.106)\end{array}$ \\
\hline Capital Only & $\begin{array}{r}-45.43^{* *} \\
(21.99)\end{array}$ & $\begin{array}{r}29.24 \\
(86.31)\end{array}$ & $\begin{array}{r}12.52 \\
(49.82)\end{array}$ & $\begin{array}{l}-23.41 \\
(32.50)\end{array}$ & $\begin{array}{r}4.284 \\
(10.89)\end{array}$ & $\begin{array}{r}-0.158 \\
(0.205)\end{array}$ & $\begin{array}{l}0.0166 \\
(0.146)\end{array}$ & $\begin{array}{l}-0.169 \\
(0.112)\end{array}$ \\
\hline Consulting \& Capital & $\begin{array}{r}-23.23 \\
(20.06) \\
\end{array}$ & $\begin{array}{r}-29.94 \\
(39.43) \\
\end{array}$ & $\begin{array}{r}7.778 \\
(34.36) \\
\end{array}$ & $\begin{array}{c}-42.33^{*} \\
(24.07) \\
\end{array}$ & $\begin{array}{r}-12.87 \\
(11.63) \\
\end{array}$ & $\begin{array}{r}-0.0159 \\
(0.192) \\
\end{array}$ & $\begin{array}{r}-0.0376 \\
(0.155) \\
\end{array}$ & $\begin{array}{r}0.104 \\
(0.117) \\
\end{array}$ \\
\hline \multicolumn{9}{|l|}{$p$ value on tests of joint significance } \\
\hline Any Consulting & 0.52 & 0.34 & 0.85 & 0.12 & 0.58 & 0.91 & 0.91 & 0.44 \\
\hline Any Capital & $0.06 *$ & 0.99 & 0.77 & 0.15 & 0.65 & 0.61 & 0.93 & 0.74 \\
\hline \multicolumn{9}{|l|}{$p$ value on tests of equality of means } \\
\hline Consulting \& Capital = Consulting & 0.29 & 0.93 & 0.42 & 0.34 & 0.25 & 0.73 & 0.53 & 0.61 \\
\hline Consulting \& Capital = Capital & 0.30 & 0.49 & 0.92 & 0.59 & 0.17 & 0.49 & 0.74 & 0.02 \\
\hline Observations & 747 & 445 & 447 & 444 & 452 & 302 & 302 & 302 \\
\hline Rounds with Data & $1,3,5,6,7,8$ & $1,5,6,8$ & $1,5,6,8$ & $1,5,6,8$ & $1,3,6,8$ & $1,6,8$ & $1,6,8$ & $1,6,8$ \\
\hline Individuals & 154 & 154 & 154 & 154 & 154 & 153 & 153 & 153 \\
\hline Outcome Mean at Baseline & 111.9 & 235.0 & 244.9 & 1.2 & 243.0 & 1.3 & 0.9 & 0.4 \\
\hline
\end{tabular}

${ }^{*} p<.10,{ }^{* *} p<.05, * * * p<.01$

Standard errors in parenthesis

Revenue, expenses and revenue less expenses all include both baseline revenue and baseline expenses as a control for consistency Profit, Revenue less expenses and profit per hour are winsorized (capped) at highest and lowest $1 \%$

Revenue, expenses and hours worked are winsorized (capped) at the highest $1 \%$

Controls for baseline value and community in all regressions 
Table 13: Profitability by Round

\begin{tabular}{|c|c|c|c|c|c|c|c|c|c|c|c|}
\hline & \multicolumn{5}{|c|}{ Income } & \multicolumn{3}{|c|}{ Revenue } & \multicolumn{3}{|c|}{ Expenses } \\
\hline & $\begin{array}{l}\text { Rnd } 3 \\
\text { Jul-09 } \\
\end{array}$ & $\begin{array}{c}\text { Rnd } 5 \\
\text { Sep-09 } \\
\end{array}$ & $\begin{array}{c}\text { Rnd } 6 \\
\text { Dec-09 }\end{array}$ & $\begin{array}{c}\text { Rnd } 7 \\
\text { Jan-10 } \\
\end{array}$ & $\begin{array}{c}\text { Rnd } 8 \\
\text { Dec-10 } \\
\end{array}$ & $\begin{array}{c}\text { Rnd } 5 \\
\text { Sep-09 } \\
\end{array}$ & $\begin{array}{c}\text { Rnd } 6 \\
\text { Dec-09 } \\
\end{array}$ & $\begin{array}{c}\text { Rnd } 8 \\
\text { Dec-10 } \\
\end{array}$ & $\begin{array}{c}\text { Rnd } 5 \\
\text { Sep-09 } \\
\end{array}$ & $\begin{array}{c}\text { Rnd } 6 \\
\text { Dec-09 } \\
\end{array}$ & $\begin{array}{c}\text { Rnd } 8 \\
\text { Dec-10 } \\
\end{array}$ \\
\hline & ols & ols & ols & ols & ols & ols & ols & ols & ols & ols & ols \\
\hline & (1) & $(2)$ & (3) & (4) & (5) & (6) & (7) & (8) & (9) & (10) & $(11)$ \\
\hline Consulting Only & $\begin{array}{c}-25.83 * \\
(13.39)\end{array}$ & $\begin{array}{r}25.67 \\
(16.74)\end{array}$ & $\begin{array}{r}-17.04 \\
(29.91)\end{array}$ & $\begin{array}{r}-15.83 \\
(40.02)\end{array}$ & $\begin{array}{r}11.35 \\
(44.69)\end{array}$ & $\begin{array}{r}24.25 \\
(26.24)\end{array}$ & $\begin{array}{r}-7.319 \\
(47.73)\end{array}$ & $\begin{array}{r}-131.2 \\
(114.0)\end{array}$ & $\begin{array}{r}5.541 \\
(13.02)\end{array}$ & $\begin{array}{r}-0.327 \\
(33.30)\end{array}$ & $\begin{array}{r}-68.33 \\
(73.77)\end{array}$ \\
\hline Capital Only & & & $\begin{array}{r}-29.21 \\
(30.31)\end{array}$ & $\begin{array}{r}-52.62 \\
(40.58)\end{array}$ & $\begin{array}{r}-74.61 \\
(46.28)\end{array}$ & & $\begin{array}{r}-3.283 \\
(48.30)\end{array}$ & $\begin{array}{r}45.69 \\
(118.4)\end{array}$ & & $\begin{array}{r}52.67 \\
(33.73)\end{array}$ & $\begin{array}{r}-25.61 \\
(76.64)\end{array}$ \\
\hline Consulting \& Capital & & & $\begin{array}{r}6.597 \\
(30.83) \\
\end{array}$ & $\begin{array}{r}-16.06 \\
(41.29) \\
\end{array}$ & $\begin{array}{r}-98.46 * * \\
(46.09) \\
\end{array}$ & & $\begin{array}{r}35.79 \\
(48.90) \\
\end{array}$ & $\begin{array}{r}-143.8 \\
(116.9) \\
\end{array}$ & & $\begin{array}{r}34.62 \\
(34.14) \\
\end{array}$ & $\begin{array}{r}-0.459 \\
(75.63) \\
\end{array}$ \\
\hline$p$ value on tests of joint sigr & & & & & & & & & & & \\
\hline Consulting \& Capital with & ılting & & 0.84 & 0.65 & 0.27 & & 0.73 & 0.17 & & 0.56 & 0.59 \\
\hline$p$ value on tests of equality & ans & & & & & & & & & & \\
\hline Consulting \& Capital = Con & & & 0.43 & 1.00 & $0.02 * *$ & & 0.37 & 0.91 & & 0.31 & 0.37 \\
\hline Consulting \& Capital = Cap & & & 0.24 & 0.37 & 0.61 & & 0.42 & 0.11 & & 0.60 & 0.74 \\
\hline Observations & 149 & 144 & 152 & 153 & 149 & 144 & 151 & 149 & 145 & 153 & 149 \\
\hline Outcome Mean at Baseline & 111.9 & 111.9 & 111.9 & 111.9 & 111.9 & 235.0 & 235.0 & 235.0 & 244.9 & 244.9 & 244.9 \\
\hline
\end{tabular}

${ }^{*} \mathrm{p}<.10,{ }^{* *} \mathrm{p}<.05, * * * \mathrm{p}<.01$

Standard errors in parenthesis

Controls for baseline value and community in all regressions

Consulting includes all 80 individuals assigned to the consulting group in rounds 3 and 5

Revenue and expenses include both baseline revenue and baseline expenses as a control for consistency

Revenue and expenses are winsorized at the highest $1 \%$ and income is winsorized at the highest and lowest $1 \%$ 
Top $10 \%$ of Income

\begin{tabular}{|c|c|c|c|c|c|}
\hline Pooled & $\begin{array}{l}\text { Rnd } 3 \\
\text { Jul-09 } \\
\end{array}$ & $\begin{array}{c}\text { Rnd } 5 \\
\text { Sep-09 }\end{array}$ & $\begin{array}{l}\text { Rnd } 6 \\
\text { Dec-09 }\end{array}$ & $\begin{array}{c}\text { Rnd } 7 \\
\text { Jan-10 }\end{array}$ & $\begin{array}{c}\text { Rnd } 8 \\
\text { Dec-10 }\end{array}$ \\
\hline (1) & (2) & (3) & (4) & (5) & (6) \\
\hline $\begin{array}{l}0.00275 \\
(0.0515)\end{array}$ & $\begin{array}{r}-0.0737 \\
(0.0507)\end{array}$ & $\begin{array}{r}0.0620 \\
(0.0584)\end{array}$ & $\begin{array}{r}-0.0491 \\
(0.100)\end{array}$ & $\begin{array}{r}-0.0195 \\
(0.111)\end{array}$ & $\begin{array}{r}0.0192 \\
(0.0999)\end{array}$ \\
\hline $\begin{array}{c}-0.0644 \\
(0.0636)\end{array}$ & & & $\begin{array}{r}-0.0857 \\
(0.102)\end{array}$ & $\begin{array}{r}-0.0119 \\
(0.112)\end{array}$ & $\begin{array}{l}-0.141 \\
(0.103)\end{array}$ \\
\hline $\begin{array}{r}-0.0659 \\
(0.0517)\end{array}$ & & & $\begin{array}{l}0.0324 \\
(0.103)\end{array}$ & $\begin{array}{r}-0.0178 \\
(0.114)\end{array}$ & $\begin{array}{r}-0.295^{* * *} \\
(0.103)\end{array}$ \\
\hline
\end{tabular}

Top 5\% of Income

\begin{tabular}{|c|c|c|c|c|c|}
\hline Pooled & $\begin{array}{c}\text { Rnd } 3 \\
\text { Sep-09 }\end{array}$ & $\begin{array}{c}\text { Rnd } 5 \\
\text { Dec-09 }\end{array}$ & $\begin{array}{c}\text { Rnd } 6 \\
\text { Dec-10 }\end{array}$ & $\begin{array}{c}\text { Rnd } 7 \\
\text { Sep-09 }\end{array}$ & $\begin{array}{c}\text { Rnd } 8 \\
\text { Dec-09 } \\
\end{array}$ \\
\hline (1) & (6) & (7) & (8) & (9) & (10) \\
\hline $\begin{array}{r}0.0161 \\
(0.0427)\end{array}$ & $\begin{array}{r}-0.0166 \\
(0.0371)\end{array}$ & $\begin{array}{r}0.0623 \\
(0.0429)\end{array}$ & $\begin{array}{r}-0.00323 \\
(0.0695)\end{array}$ & $\begin{array}{r}-0.115 \\
(0.0934)\end{array}$ & $\begin{array}{r}0.0821 \\
(0.0783)\end{array}$ \\
\hline $\begin{array}{r}-0.0650 \\
(0.0460)\end{array}$ & & & $\begin{array}{r}-0.0701 \\
(0.0704)\end{array}$ & $\begin{array}{c}-0.173^{*} \\
(0.0947)\end{array}$ & $\begin{array}{r}-0.0159 \\
(0.0810)\end{array}$ \\
\hline $\begin{array}{r}-0.0337 \\
(0.0425)\end{array}$ & & & $\begin{array}{l}0.00947 \\
(0.0716)\end{array}$ & $\begin{array}{r}-0.113 \\
(0.0963)\end{array}$ & $\begin{array}{r}-0.113 \\
(0.0807)\end{array}$ \\
\hline
\end{tabular}

$p$ value on tests of joint significance

Consulting \& Capital with Consulting

Consulting \& Capital with Capital

0.12

0.80

\begin{tabular}{|c|c|c|c|c|c|c|c|c|c|c|c|}
\hline 0.47 & & & 0.92 & 0.85 & 0.12 & 0.80 & & & 0.96 & 0.17 & 0.82 \\
\hline 0.17 & & & 0.76 & 0.88 & $0.02 * *$ & 0.18 & & & 0.62 & $0.09 *$ & 0.36 \\
\hline 0.22 & & & 0.42 & 0.99 & $0.00 * * *$ & 0.31 & & & 0.86 & 0.98 & $0.01 *$ \\
\hline 0.98 & & & 0.25 & 0.96 & 0.14 & 0.53 & & & 0.26 & 0.53 & 0.23 \\
\hline 747 & 149 & 144 & 152 & 153 & 149 & 747 & 149 & 144 & 152 & 153 & $\overline{149}$ \\
\hline 154 & & & & & & 154 & & & & & \\
\hline
\end{tabular}

$p$ value on tests of equality of means

Consulting \& Capital $=$ Consulting

Consulting \& Capital = Capital

Observations

154

$\frac{\text { Individuals }}{* \mathrm{p}<.10, * * \mathrm{p}<.05, * * * \mathrm{p}<.01}$

Standard errors in parenthesis

Controls for baseline value and community in all regressions

Consulting includes all 80 individuals assigned to the consulting group in rounds 3 and 5 
Table 14: Operations by Round

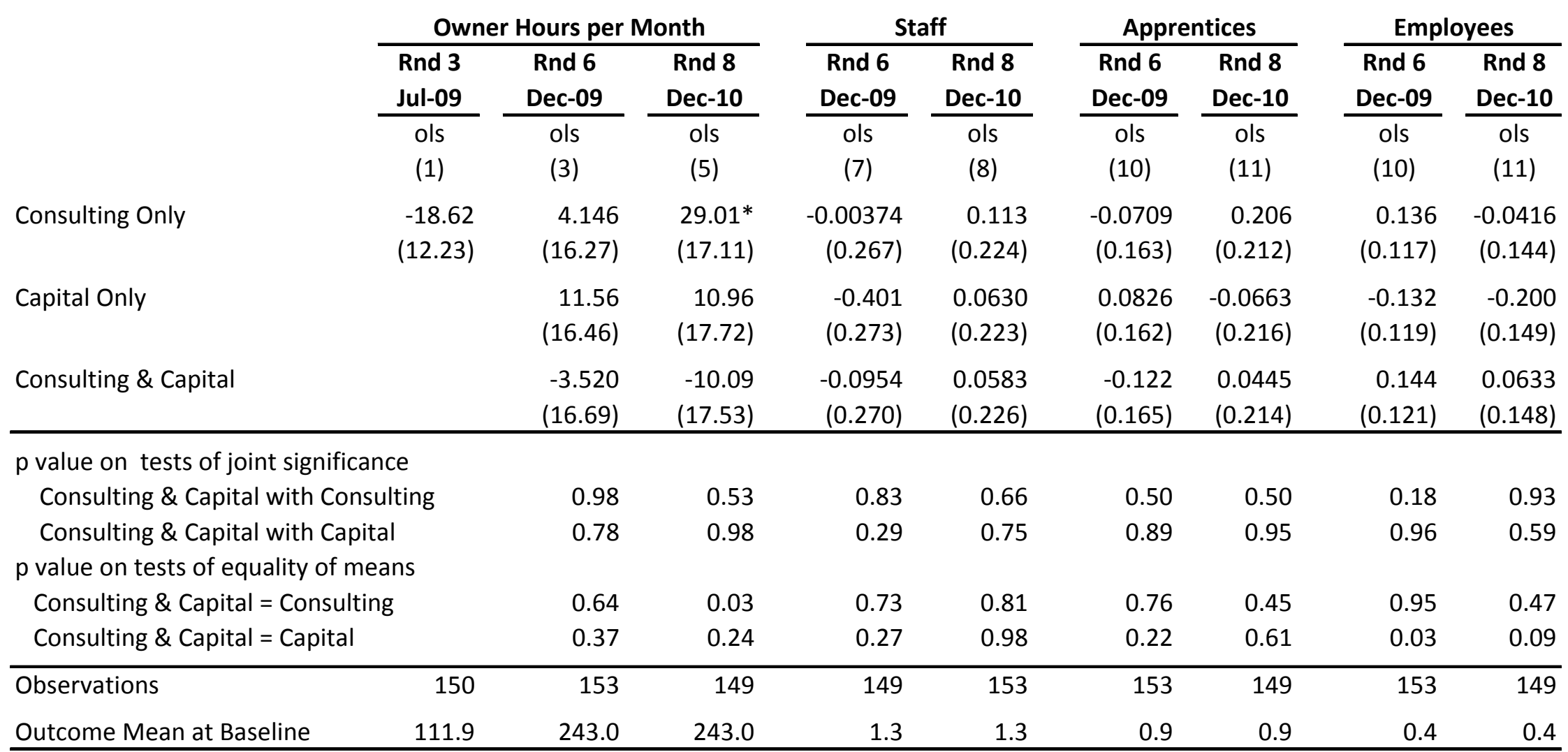

${ }^{*} \mathrm{p}<.10,{ }^{* *} \mathrm{p}<.05,{ }^{* * *} \mathrm{p}<.01$

Standard errors in parenthesis

Controls for baseline value and community in all regressions 
Table 15: Recall Test: Sum of Daily Visits versus End-of-Month

\begin{tabular}{|c|c|c|c|c|c|c|c|}
\hline & $\overline{\text { Revenue }}$ & $\begin{array}{l}\text { Revenue } \\
\text { Squared }\end{array}$ & Expenses & $\begin{array}{l}\text { Expenses } \\
\text { Squared }\end{array}$ & $\begin{array}{c}\text { Rev less Exp } \\
\text { Dec-10 }\end{array}$ & $\begin{array}{c}\text { Rev less Exp } \\
\text { Squared }\end{array}$ & $\begin{array}{l}\text { Days } \\
\text { Found in } \\
\text { September }\end{array}$ \\
\hline & ols & ols & ols & ols & ols & ols & ols \\
\hline & (1) & (2) & (3) & (4) & (5) & (6) & (6) \\
\hline Consulting & $\begin{array}{r}-4.081 \\
(29.64) \\
\end{array}$ & $\begin{array}{r}22895.1^{* *} \\
(9744.0) \\
\end{array}$ & $\begin{array}{r}8.712 \\
(16.09) \\
\end{array}$ & $\begin{array}{r}9032.5^{* *} \\
(4226.1) \\
\end{array}$ & $\begin{array}{r}-2.402 \\
(30.44) \\
\end{array}$ & $\begin{array}{r}7626.5 \\
(12405.4) \\
\end{array}$ & $\begin{array}{r}-1.159 * \\
(0.654) \\
\end{array}$ \\
\hline Observations & 124 & 124 & 122 & 122 & 126 & 126 & 147 \\
\hline
\end{tabular}

$*_{\mathrm{p}}<.10, * * \mathrm{p}<.05, * * * \mathrm{p}<.01$

Standard errors in parenthesis

Controls for baseline value, community and days with information.

Consulting includes all 80 individuals assigned to the consulting group

Revenue and expenses include both baseline revenue and baseline expenses as a control for consistency

Revenue and expenses are winsorized at the highest $1 \%$ and income is winsorized at the highest and lowest $1 \%$

Results are restricted to those individuals that we found at least 20 times in August 


\section{Appendix A: Ernst \& Young Team}

The four Ernst \& Young consultants were supervised by a Director and a Partner at Ernst \& Young - Ghana, and monitored by field staff at Innovations for Poverty Action - Ghana.

\section{Consultant A}

Consultant A is an assistant manager in the Business Advisory Service line of Ernst \& Young, Ghana. He has 6 years of experience in business process reviews, monitoring and evaluation, financial re-engineering, fund management, monitoring and evaluation and internal audit. He has been involved in number of Performance Improvement related assignments in both private and public sectors. He joined Ernst \& Young in 2007 and is currently based in the Accra Office. Prior to joining Ernst \& Young, Consultant A worked with TOTAL Petroleum Ghana Limited as Internal Auditor.

Consultant A was team leader in the 'Returns to Business Management Consulting Study' engagement undertaken for Innovations for Poverty Action (IPA). Consultant A holds a Bachelors degree in Administration (Accounting) from the University of Ghana and a MBA in Financial Management from the University of Hull. He is a member of the Association of Chartered Certified Accountants (UK).

\section{Consultant B}

Consultant B is a Manager in Advisory Service Line and engaged in the provision of performance improvement services, including monitoring and evaluation (M\&E) for clients in the public and private sector. Consultant B has over 6 years of experience in diverse areas, including Monitoring and Evaluation, Policy Analysis, Project Management, Training, Strategy Planning, Communication, Advocacy and Campaigns and Fundraising, Knowledge Management and consultancy. He joined Ernst \& Young Ghana in 2008 and is based in the Accra office. He has work experience in Ghana, Sierra Leone and Liberia before joining Ernst \& Young.

Consultant B holds a Master of Science in Development Policy and Planning and a Bachelor of Science in Development Planning. He is a member of Ghana Monitoring and Evaluation forum.

\section{Consultant C}

Consultant B Mensa is a Manager with Ernst \& Young and has experience in Human Resource Management. Her areas of focus include HR Reorganization and Management, Training, Human Resource Policies and Procedures, Salary Surveys and Performance Management. She has highly developed research abilities and has led and supported Capacity Development and Institutional Strengthening assignments for clients both in the Public and Private Sectors. 
Consultant $B$ has been involved in various roles, from support to managing, in a number of engagements. She joined Ernst \& Young in 2004 and is based in the Accra office.

\section{Consultant D}

Consultant $D$ is a Manager with Business Advisory Services within Ernst \& Young focusing more on training and human resource management. She joined Ernst \& Young in 2007 and is based in the Accra office. She has over 18 years work experience and prior to joining Ernst \& Young, Consultant D worked with the World Vision, SNV-Ghana (Netherlands Development Organisation), African Centre for Human Development and DANIDA Volta Region Water and Sanitation Project. She holds a BSc. Administration (Human Resource Management) from the Central University College, Ghana. 


\section{Appendix D: Training Modules}

\begin{tabular}{|c|c|c|}
\hline & Module & Description \\
\hline 1 & Record Keeping & $\begin{array}{l}\text { - Gave respondents two books that covered procurement, sales, stock, } \\
\text { cash in/out, wages, assets, etc. } \\
\text { - Rationale for adopting bookkeeping: tracking revenue and expenses } \\
\text { gives you a clearer picture of your financial situation } \\
\text { - Remember to track indirect costs. Most were actually earning less } \\
\text { than they thought they were before they started bookkeeping and } \\
\text { including indirect costs } \\
\text { - Monitored record keeping over the year } \\
\text { - Took them through a monthly income statement for } 1 \text { month then } \\
\text { - monitored their own calculations of monthly income } \\
\text { - Separation of business and personal finances } \\
\text { employee of the business. You are therefore entitled to both a share } \\
\text { of the profits and a wage (wage is determined through costing) }\end{array}$ \\
\hline 2 & Procurement & $\begin{array}{l}\text { - Initially just-in-time buyers, purchasing what they need for each job } \\
\text { - Advised to buy weekly stock to get bulk discounts and reduce time } \\
\text { spent on travel } \\
\text { - Also pay particular attention to the quality of bulk purchases - look } \\
\text { out for high quality inputs }\end{array}$ \\
\hline 3 & Operational Activities & $\begin{array}{l}\text { Very specific to the circumstances of each business. Some examples: } \\
\text { - Keeping your shop tidy can make customers more comfortable and } \\
\text { more willing to pay a higher price if they can see that you are serious } \\
\text { about the business } \\
\text { - Need to assure consistent supply of electricity by applying pressure to } \\
\text { the service providers } \\
\text { - Try to charge advance every time, especially if the client is new, } \\
\text { although it can be waived for reliable clients. (If business was slow, } \\
\text { - } \text { they were reluctant to charge advance) } \\
\text { - } \text { Arrange your production process for efficiency: when should you do } \\
\text { - cutting? Who should do what? } \\
\text { - Quality control: Monitoring of worker and apprentices } \\
\text { to save for a knitting machine yourself? }\end{array}$ \\
\hline 4 & Motivation of workers & $\begin{array}{l}\text { - How do you motivate your workers to get the best out of them? } \\
\text { - Need to make their workers feel like they are part of the team } \\
\text { - Reward them adequately: they have their own financial issues, just as } \\
\text { you do } \\
\text { - If there are any apprentices that you really want to keep, tip them } \\
\text { some money regularly }\end{array}$ \\
\hline
\end{tabular}




\begin{tabular}{|c|c|c|}
\hline & & $\begin{array}{l}\text { - Apprentices should be trained in customer service and should see } \\
\text { themselves as more than just students } \\
\text { - If your workers work particularly hard on something, give them } \\
\text { something extra } \\
\text { - Give workers training and teach them what you know so they can } \\
\text { - handle things when you are out of the shop } \\
\text { - Advised to formalize agreements with employees }\end{array}$ \\
\hline 5 & Value Addition & $\begin{array}{l}\text { - Accept feedback and apply recommendations } \\
\text { - Good finishing can be a source of sales, especially in conjunction w/ } \\
\text { labels } \\
\text { - Diversify from core business: add selling fabrics, selling inputs, buy } \\
\text { knitting machine and take subcontracted jobs } \\
\text { - Keep in touch w/ new designs, learn new skills and/or develop your } \\
\text { own designs. You can then take subcontracted jobs as well if the } \\
\text { knowledge/technique isn't common }\end{array}$ \\
\hline 6 & Time management & $\begin{array}{l}\text { - Planning for the business: set a time that you should be able to reach } \\
\text { - Hour investment goals (Eg, I will get a new container by April) } \\
\text { when they can stop by } \\
\text { - Set realistic deadlines w/ customers that you can actually meet } \\
\text { - Give an allowance when calculating customer deadlines in case there } \\
\text { is a power outage. If timing is a consistent issue, leave one day a week } \\
\text { open to handle emergencies } \\
\text { - If you know you can't deliver on time, call the client in advance to let } \\
\text { them know } \\
\text { - If a customer is pushing for a tight deadline, charge a higher rate to } \\
\text { compensate for you overtime }\end{array}$ \\
\hline 7 & Costing & $\begin{array}{l}\text { A major exercise after bookkeeping was introduced. } \\
\text { - Took them through calculating the cost of making each product } \\
\text { including indirect expenses, taxes \& wages to determine how much } \\
\text { they should charge for each one. } \\
\text { - Many were undercharging, but found it difficult to raise the price if all } \\
\text { the other tailors in the area are also undercharging } \\
\text { - Introduced the need to account for their own time by asking how } \\
\text { much they should charge for their own time (if you were to get } \\
\text { someone like you to do this job, how much would you pay them? That } \\
\text { is what you can set as your wage) } \\
\text { - Need to add indirect costs such as rent and electricity (How many do } \\
\text { you sew in a month? Divide the monthly rent/indirect cost by that } \\
\text { number to get the cost per unit) } \\
\text { - Need to add some profit as well }\end{array}$ \\
\hline 8 & Customer Service & $\begin{array}{l}\text { - How to receive customers: greeting them, saying thank you, } \\
\text { accommodating their concerns with workmanship }\end{array}$ \\
\hline
\end{tabular}




\begin{tabular}{|c|c|c|}
\hline & & $\begin{array}{l}\text { - Doing something different that will cause your customer to always } \\
\text { come to you: give something over Christmas like a handkerchief w/ } \\
\text { your business name printed on it, or dash them a dress if you are } \\
\text { sewing plenty. } \\
\text { - Know the individual customers and what they like } \\
\text { - Create a database w/ customer names, phone numbers \& where they } \\
\text { live so you can call ones you haven't seen in a long time } \\
\text { - Closely related to time management } \\
\text { - Sewing well isn't enough: need to also meet deadlines, treat them } \\
\text { - nicely, make alterations for free, and so on } \\
\text { - Customer service is the key to building a base of loyal customers } \\
\text { - Package things nicely for customers and use labels }\end{array}$ \\
\hline 9 & Security of shop & $\begin{array}{l}\text { - Have someone sleep in the store at night for security } \\
\text { - Change the locks/buy more secure padlocks. } \\
\text { - Keep valuables at home if possible. } \\
\text { - If they have a wooden kiosk, can they save for a container? }\end{array}$ \\
\hline 10 & Sales and Marketing & $\begin{array}{l}\text { Most viewed time spent marketing as competing with time spent sewing } \\
\text { - Market your products through labels, finishing, customer service, } \\
\text { - } \text { displaying sewn items } \\
\text { - fubric right from your shop. } \\
\text { - Help your customers to understand why you charge the prices you do } \\
\text { if they think that the price is high } \\
\text { - Go to offices/businesses/schools to let them know about your } \\
\text { - } \text { product } \\
\text { - Call customers that haven't visited in a while } \\
\text { - Register business as this can be necessary for large contracts } \\
\text { - When you get the contract, formalize terms of payment and } \\
\text { - Get a signboard if you don't already have one. } \\
\text { - Making sure you kiosk isn't an eyesore: look presentable! }\end{array}$ \\
\hline 11 & $\begin{array}{l}\text { Lifestyle in relation to } \\
\text { work/life }\end{array}$ & $\begin{array}{l}\text { - How do you balance child rearing/other household responsibilities } \\
\text { and business? Do you need to work early or late or work from home } \\
\text { - sometimes? } \\
\text { - Need to rest to maintain stamina } \\
\text { - Dress professionally as if you come to work, not casually as if you're at } \\
\text { - Home } \\
\text { - See a doctor regularly and check your blood pressure }\end{array}$ \\
\hline 12 & $\begin{array}{l}\text { Financing of } \\
\text { business/savings }\end{array}$ & $\begin{array}{l}\text { - If you want to be able to grow, the best source for cash is retained } \\
\text { profits. Identify how much you can save through your bookkeeping }\end{array}$ \\
\hline
\end{tabular}




\begin{tabular}{|c|c|c|}
\hline & & $\begin{array}{l}\text { - Advised against getting a loan unless they have a concrete goal and } \\
\text { plan to repay the principal and interest. } \\
\text { o If you do to take a loan, top it up with savings to keep the amount } \\
\text { borrowed low. } \\
\text { o Pay particular attention to how much interest you will be paying. } \\
\text { Ask them to calculate the amount of cash you will actually pay as } \\
\text { interest instead of talking about it as a percentage } \\
\text { - If you don't have a bank account, open one. If you don't have a } \\
\text { separate business account, open one. } \\
\text { - Don't dip hands into business money } \\
\text { - Buy treasury bills for savings }\end{array}$ \\
\hline 13 & Business Growth & $\begin{array}{l}\text { - Identify concrete goals for expansion } \\
\text { o How much will it cost to reach your goal? } \\
\text { o How much would you have to save every week to get that much } \\
\text { money? } \\
\text { o If the savings goal is realistic, no need to take a loan } \\
\text { o If the savings goal is unrealistic, a loan + savings might be } \\
\text { worthwhile } \\
\text { - If you consider a new location, be sure that the land rights are secure } \\
\text { o Is a new location necessary or could your problems be solved } \\
\text { through better marketing? } \\
\text { - If you know that there is a weakness in your skills set, take a course } \\
\text { with a fashion school or association } \\
\text { - Objective setting; short term, medium term and long term } \\
\text { - Apart from sewing, what else can you do? Add on other businesses to } \\
\text { - Srotect against the seasonality of sewing } \\
\text { - How will your grow your customer base? } \\
\text { o As your customer base is growing, how do you keep meeting your } \\
\text { - Modeadines? Additional workers? Better machines? } \\
\text { - If you have a specific need that requires investments to meet your } \\
\text { customer demands, you can go in for a loan }\end{array}$ \\
\hline
\end{tabular}




\section{Appendix C: Examples of Mentorship}

\begin{tabular}{|c|c|}
\hline Client & Consultant's Notes \\
\hline 819 & $\begin{array}{l}\text { Introduced bookkeeping and she adopted it and maintained records consistently. Wants to } \\
\text { be a designer so advised her to seek a training course. Starting doing some more marketing } \\
\text { but she is near the limit of her capacity so they developed plans to increase capacity by } \\
\text { hiring a worker. Has expanded her shop a lot and took on an apprentice. Got connected to } \\
\text { electricity and keeps a very clean shop. Adopted labels and sales of materials. Aims at a } \\
\text { higher end customer. Responded to questions; client really embraced the consultancy. }\end{array}$ \\
\hline 810 & $\begin{array}{l}\text { Covered all models but he wasn't very interested in actually adopting new ideas. Wants to } \\
\text { relocate his shop. Sews uniforms for school sports teams. Thinks that since he's approaching } \\
\text { retirement it's not necessary to be aggressive about expanding and he wants to move his } \\
\text { shop. Advised to do aggressive marketing for schools \& use calling cards }\end{array}$ \\
\hline 402 & $\begin{array}{l}\text { Was suspicious of consultancy at first but really caught on. Registered her business, buys in } \\
\text { bulk, keeps records, started using labels, dashes customers toffees. Developed plan to get a } \\
\text { new apprentice. Wants to relocate to a place on the main road and discussed issues } \\
\text { involved in moving. Will often ask questions about the decisions she's facing. }\end{array}$ \\
\hline 415 & $\begin{array}{l}\text { Has a second job sewing for industrial sewing shop so he's often not in the shop. Even when } \\
\text { he's around he is not open regularly. Met him late in the year \& didn't spend much time } \\
\text { together. }\end{array}$ \\
\hline 304 & $\begin{array}{l}\text { Sews under a tree. Started well w/ bookkeeping although stopped along the line. } \\
\text { Opened a bank account and was saving through account, also bought t-bills. No employees. } \\
\text { Raised prices a bit before Christmas. Sews well \& has good customer relations. Started } \\
\text { insisting on advance. }\end{array}$ \\
\hline 309 & $\begin{array}{l}\text { Was big on record keeping before she feel sick. Very disciplined w/ finances. Help provide } \\
\text { structure for her saving, separating business } \& \text { personal expenses, paying self wage. Was } \\
\text { sick, lost her mother, then got sick again, so we didn't have as much time together. Went } \\
\text { through costing \& value addition but doesn't have employees. Didn't cover sales/marketing. } \\
\text { Already had good customer service. Lifestyle was an important topic. Started insisting on } \\
\text { advance. }\end{array}$ \\
\hline 709 & $\begin{array}{l}\text { Initially difficult to convince of the value of consulting but became more receptive over } \\
\text { time. Discussed diversifying away from sewing only suits. Tried sewing shirts and was } \\
\text { overwhelmed by their popularity. Has a huge potential if he can diversify his products and } \\
\text { do enough marketing. Discussed bookkeeping but he stopped along the line, although he } \\
\text { has a good memory. Discussed savings. Wants to move to a new place (w/ help in financing } \\
\text { from one of his customers). Procurement: started buying enough for } \sim 5 \text { suits at once. } \\
\text { Interested in labels for suits and branding on bags. Was sick for a month so discussed health } \\
\text { issues. }\end{array}$ \\
\hline 713 & $\begin{array}{l}\text { Very unreceptive at the start but warmed up eventually. Started insisting on advance and } \\
\text { changed prices based on costing. Had a special interest in selling raw materials and used the } \\
\text { capital drop for this after some discussion. Is moving shops. Opened a bank account for the } \\
\text { first time with the money from the money games (the } 6 \text { Cedis). Has also started saving. } \\
\text { Didn't really take up bookkeeping at all (may be only semi-literate). Talked about value } \\
\text { addition but she didn't implement it. Didn't really cover marketing at all. }\end{array}$ \\
\hline 509 & $\begin{array}{l}\text { Didn't spend much time on record keeping because she was already keeping records on a } \\
\text { computer. Has several other businesses in addition to sewing. Discussed strategies to get } \\
\text { more retailers to sew for and open up her own retail shop. Is taking a professional course in } \\
\text { marketing. }\end{array}$ \\
\hline
\end{tabular}




\begin{tabular}{|c|c|}
\hline 515 & $\begin{array}{l}\text { Is considering taking a loan of GHc } 1000 \text { to buy knitting and babylocking machines so they } \\
\text { discussed financing in detail. Covered all } 13 \text { modules. Learned a new sewing technique that } \\
\text { she now does for other seamstresses. Advised to learn to sew men's clothes to expand } \\
\text { market, which she did. Has a market stall in addition to shop that she isn't using so advised } \\
\text { her to work from both locations at once. }\end{array}$ \\
\hline 217 & $\begin{array}{l}\text { Went beyond basic record keeping to the preparation of monthly income statement. She } \\
\text { focuses on higher-end market and discussed where she can find workers who meet her } \\
\text { quality standards. Decided to hire someone who just graduated polytechnic. Discussed } \\
\text { using savings to purchase quality machines. Discussed her plans to return to school to study } \\
\text { business, and developed plans to start taking on apprentices w/ an SSS education who want } \\
\text { to become designers, almost as an academy. }\end{array}$ \\
\hline 209 & $\begin{array}{l}\text { Wants to buy an industrial machine w/ IPA grant so they worked on saving to top up the } \\
\text { price and arranging her space so she can fit it. Her location is small so they worked on } \\
\text { finding a second place (and leaving a worker at the current one). Expansion limited by the } \\
\text { space that she had available }\end{array}$ \\
\hline 111 & $\begin{array}{l}\text { Is semi-literate so they covered bookkeeping using symbols. Main problem is w/ an } \\
\text { unreliable worker. Consultant spoke with the worker about her dedication } \& \text { advised owner } \\
\text { to try to find another worker. Has a school next door who would give him a larger contract if } \\
\text { he had more reliable help. Discussed banking, retirement and customer service. Wants to } \\
\text { get a good worker who can manage the business so he can farm and stop sewing. }\end{array}$ \\
\hline 119 & $\begin{array}{l}\text { Sews in his house \& doesn't have a signboard so his market is small. Discussed getting a } \\
\text { signboard and focusing on getting larger contracts to anchor his business while his wife } \\
\text { conducts marketing for him to try to grow individual customer base. Will complete tasks } \\
\text { outside of meetings. }\end{array}$ \\
\hline 608 & $\begin{array}{l}\text { Implements advise very quickly! She made handkerchiefs for X-Mas and gave them out to } \\
\text { customers. Started using dress labels. Got business registration forms but is yet to fill them } \\
\text { out. Started offering customers minerals for free but then charges them a little bit extra for } \\
\text { the sewing to cover the minerals cost. Hired a worker. Advised to get a computer for record } \\
\text { keeping/customer database because she is growing very quickly }\end{array}$ \\
\hline 618 & $\begin{array}{l}\text { Got a contract recently that the consultant helped negotiate/review the details on. Semi- } \\
\text { literate so he asked a brother to keep records for him, although the consultant also advised } \\
\text { him to try to use symbols to write the way he understands. Focused on utilizing his bank } \\
\text { account for savings. Also discussed labels. His brother will help him sew but isn't reliable so } \\
\text { needs a worker. Used to sell shirts and the consultant advised him to restart this and do sew } \\
\text { and sell. }\end{array}$ \\
\hline
\end{tabular}




\section{Appendix D: Examples of Tailors}

A tailor who shares his small wooden shop with another tailor

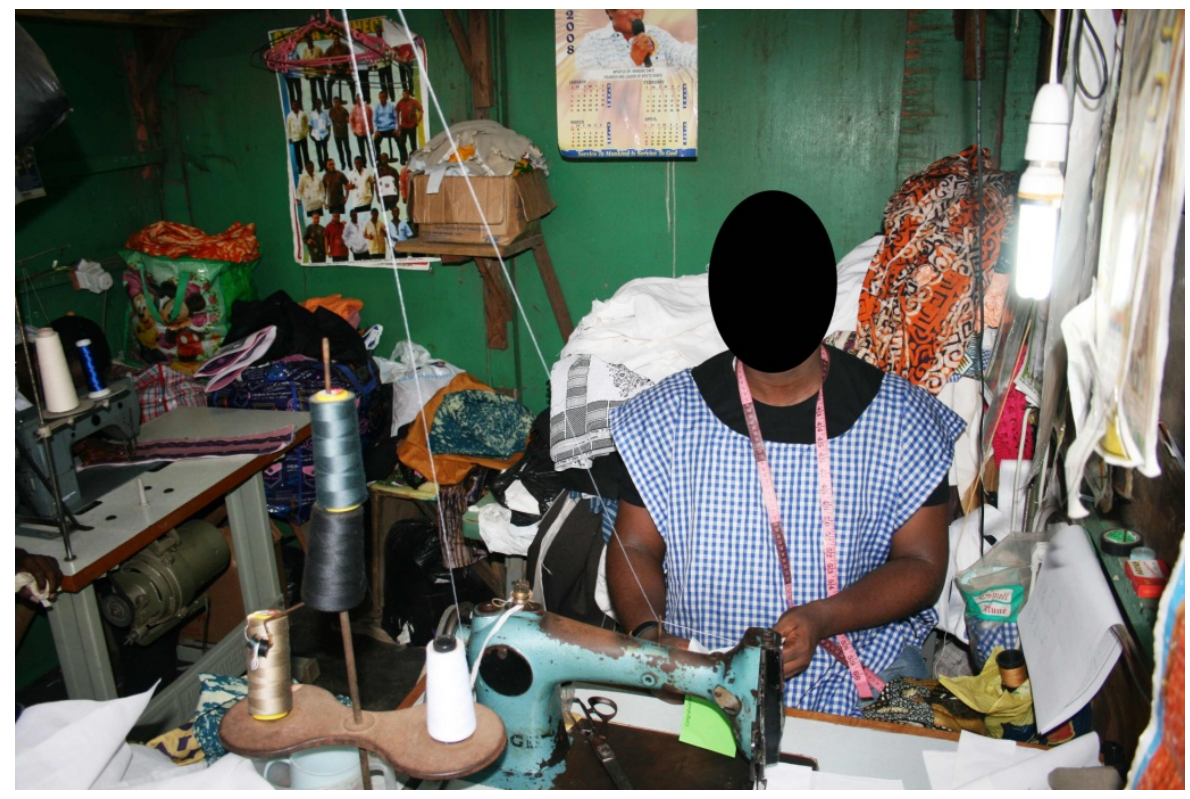

A tailor operating out of a crowded market stall, with several apprentices.

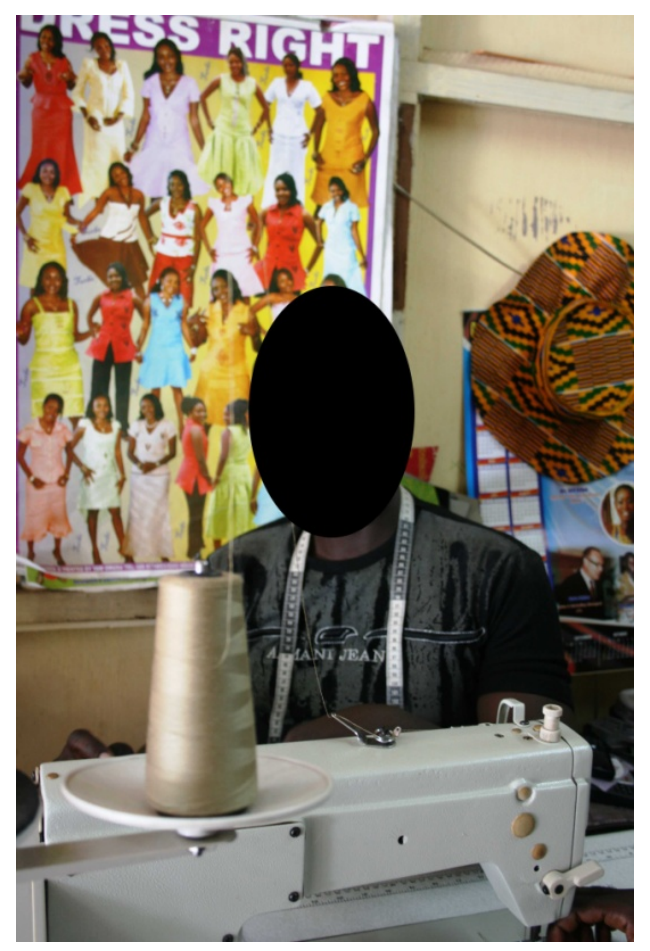


A tailor working out of a kiosk.

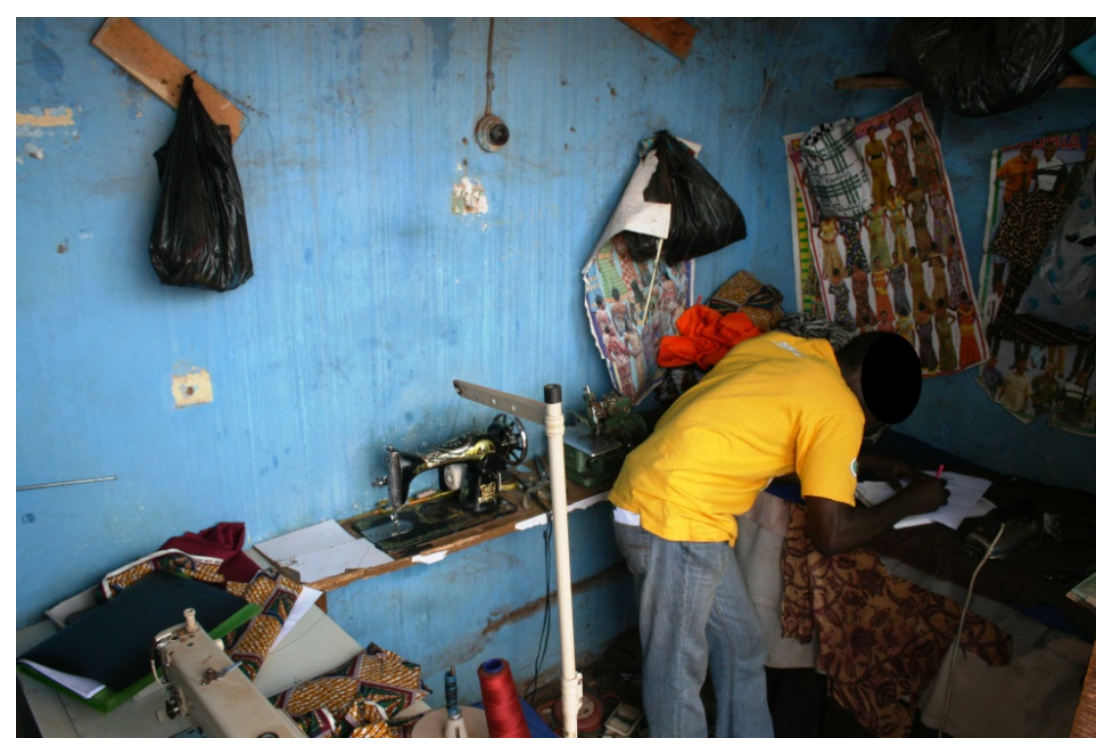

A tailor who owns rents space in a concrete building.

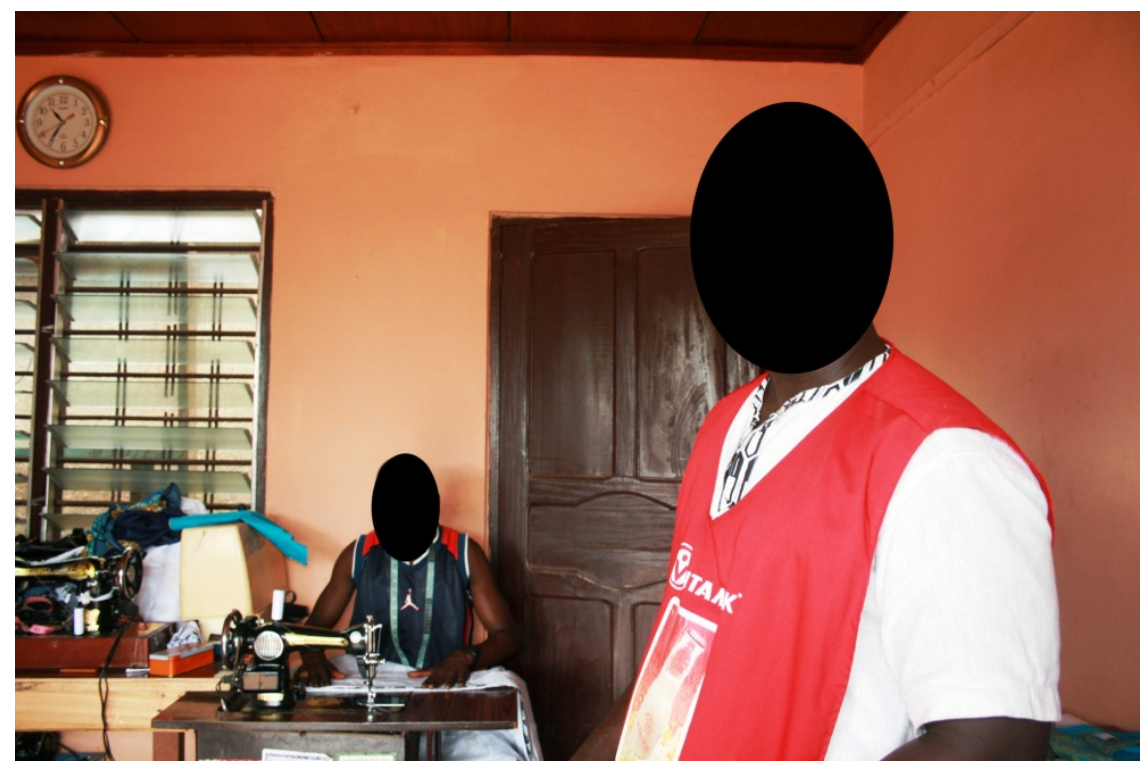


A tailor who shares a kiosk.

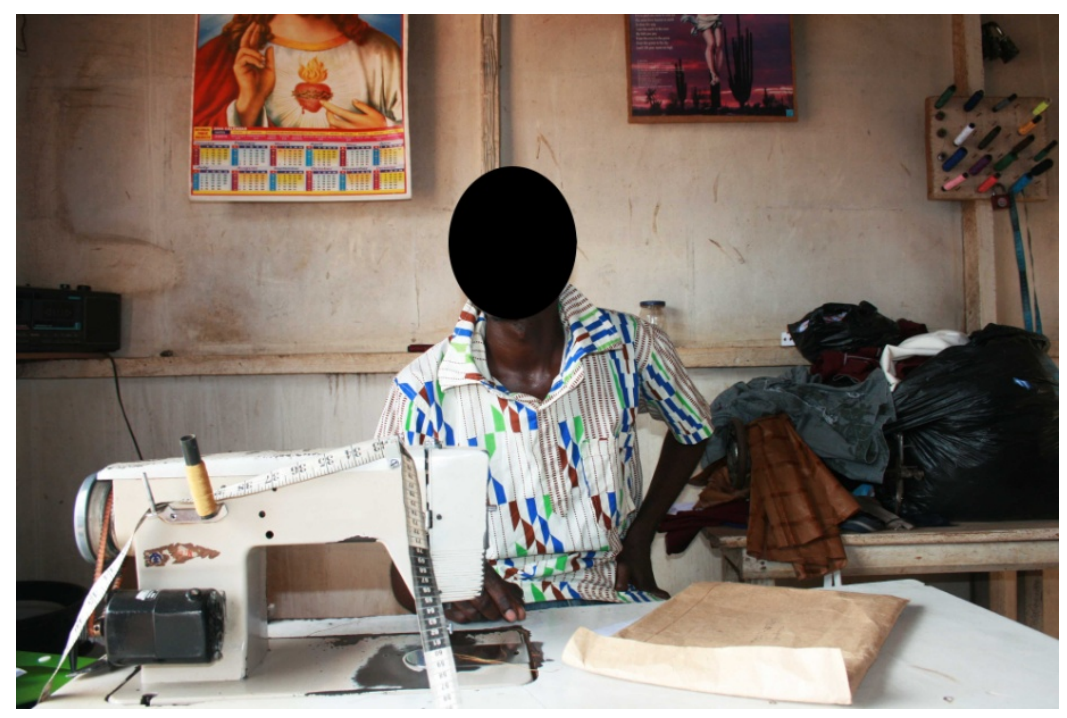

A seamstress who owns a converted shipping container

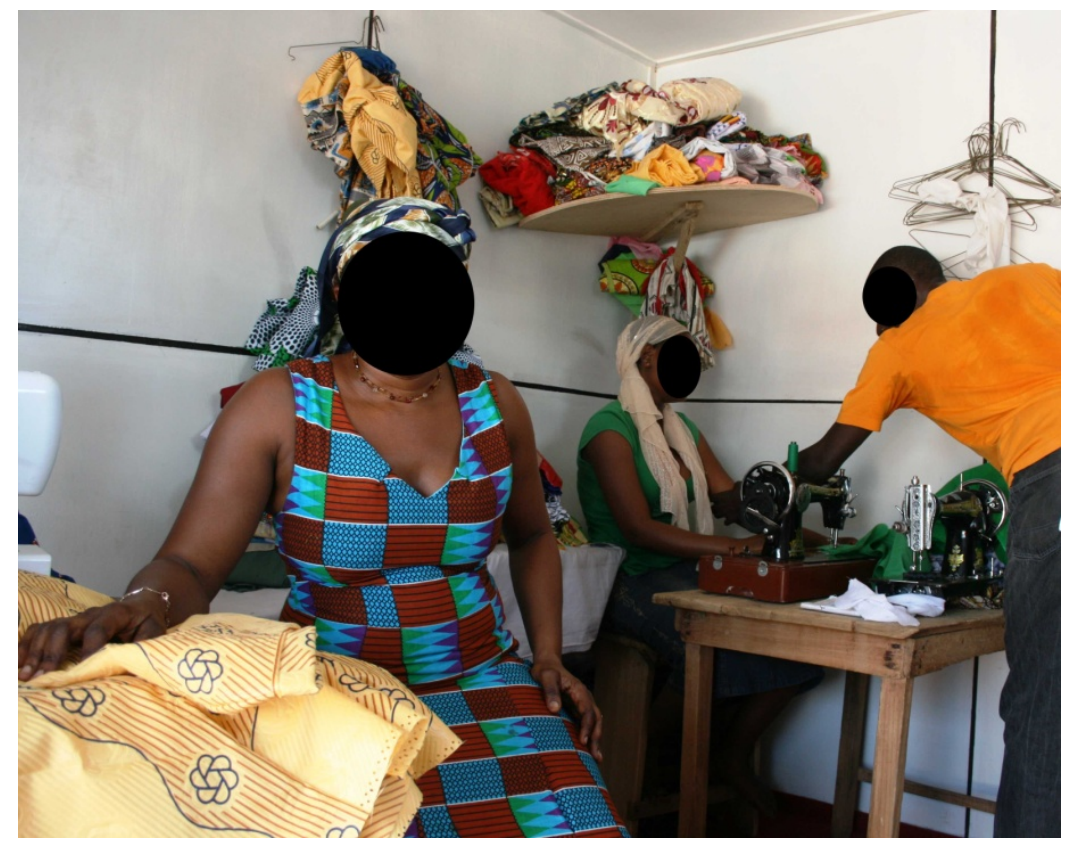


A tailor in his wooden shop.

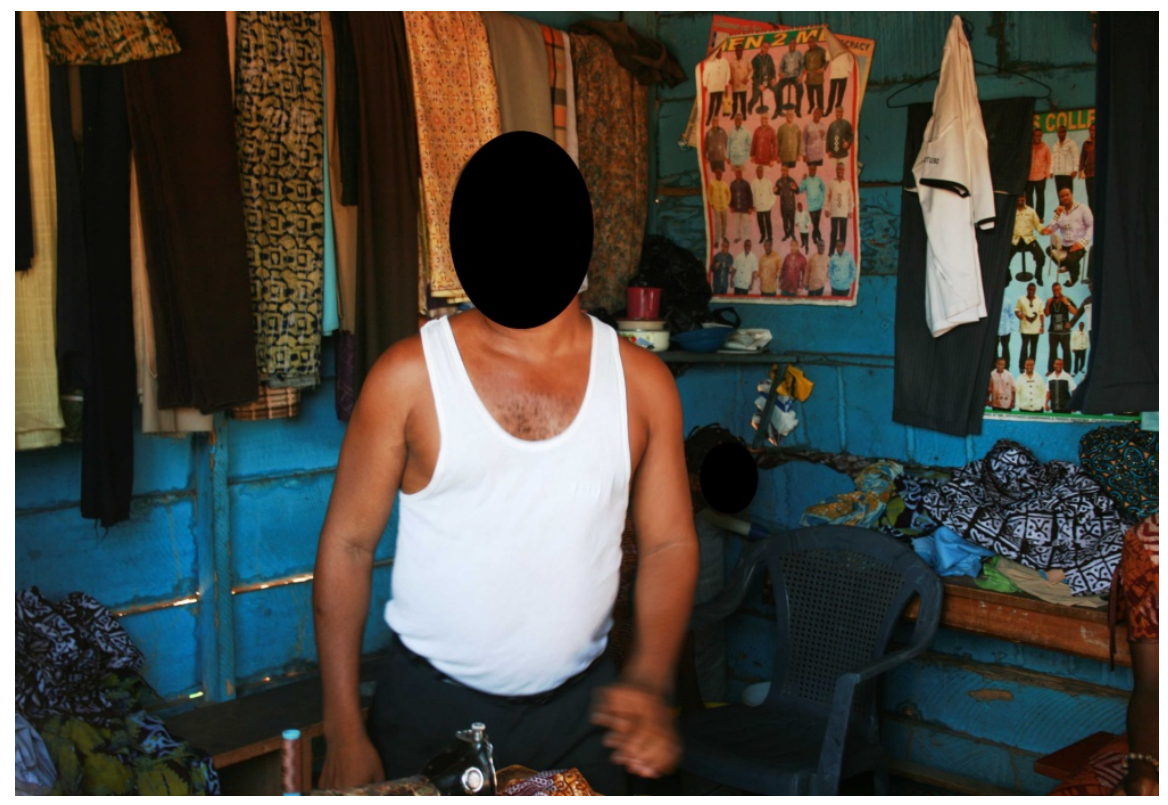

